TITLE:

\title{
A new species of Petrochromis (Perciformes: Cichlidae) from Lake Tanganyika
}

\section{$\operatorname{AUTHOR(S):~}$}

Takahashi, Tetsumi; Koblmüller, Stephan

\section{CITATION:}

Takahashi, Tetsumi ...[et al]. A new species of Petrochromis (Perciformes: Cichlidae) from Lake Tanganyika. Ichthyological Research 2014, 61(3): 252-264

ISSUE DATE:

2014-04-05

URL:

http://hdl.handle.net/2433/198634

\section{RIGHT:}

The final publication is available at Springer via http://dx.doi.org/10.1007/s10228-0140396-9.; この論文は出版社版でありません。引用の際には出版社版をご確認ご利用くだ さい。; This is not the published version. Please cite only the published version. 
3 A new species of Petrochromis (Perciformes: Cichlidae) from Lake Tanganyika

5 Tetsumi Takahashi ${ }^{1}$ and Stephan Koblmüller ${ }^{2}$

$7 \quad{ }^{1}$ Department of Zoology, Graduate School of Science, Kyoto University,

8 Kitashirakawa-Oiwake, Sakyo, Kyoto 606-8502, Japan, e-mail:

9 tetsumi@terra.zool.kyoto-u.ac.jp

10

112 Department of Zoology, Karl Franzens University Graz, Universitätsplatz 2, 8010 Graz, 12 Austria 
13 Based on morphological and molecular analyses of a Petrochromis fish (Cichlidae) from the

14 southern end of Lake Tanganyika, this fish is considered a taxonomic species distinct from

15 the six known congeners. A new scientific name is proposed for this fish. A key to the seven

16 Petrochromis species is included.

17

18 Key words Taxonomy $\cdot$ Morphology $\cdot \operatorname{mtDNA}$ phylogeny $\cdot$ Description of a new species ·

19 Key to species 


\section{Introduction}

Lake Tanganyika in the East African Rift Valley (Fig. 1) harbours morphologically, ecologically, and genetically exceptionally diverse cichlid species assemblage. About 200

24 cichlid species have been described so far for Lake Tanganyika (Koblmüller et al. 2008a),

25 and new species are still being discovered (e.g., Takahashi and Hori 2006; Schelly et al.

26 2007; Verburg and Bills 2007; Takahashi 2008; Burgess 2012; Kullander et al. 2012), such

27 that the total number of species may reach 250 (Snoeks 2000). Most of these species are endemic to the lake and this cichlid radiation most likely originated via intra-lacustrine speciation after the lake was established 9-12 million years ago (Cohen et al. 1993; Koblmüller et al. 2008a). Due to this high diversity and rapid cladogenesis, these fish are

31 important model systems for studying the factors and processes underlying adaptive 32 radiation (e.g., Fryer and Iles 1972; Kornfield and Smith 2000; Turner et al. 2001; Kocher

33 2004; Seehausen 2006; Turner 2007; Koblmüller et al. 2008a; Salzburger 2009; Sturmbauer

34 et al. 2011; Takahashi and Koblmüller 2011; Gante and Salzburger 2012).

Tropheini Poll 1986 is one of the most species-rich cichlid tribes endemic to the lake. In this tribe, 23 mouth-brooding species are currently considered valid and belong to seven genera

38 (genus allocation for two species is not resolved, Takahashi 2003). Molecular phylogenetic

39 studies indicate that this tribe forms a monophyletic group within the so-called "modern

40 haplochromines", sister to the extremely species-rich lineage that includes the species flocks

41 of Lake Malawi and the Lake Victoria region as well as numerous riverine taxa (Salzburger et 
42 al. 2005; Koblmüller et al. 2008b). Petrochromis Boulenger 1898 is a genus belonging to this

43 tribe (Poll 1986; Takahashi 2003). This genus is morphologically defined by having a

44 brush-like tooth plate on each jaw (Poll 1986), which allows the fish to comb unicellular

45 algae from filamentous algae on rocks (Yamaoka 1983a). These tooth plates are composed of

46 tricuspid teeth arranged in irregular rows, and the shape of the outer teeth does not differ from

47 the inner teeth (e.g., Poll 1956: figs. 18, 20), whereas in the other species of the tribe

48 Tropheini, the outer teeth are clearly different from the inner teeth. They are bicuspid in

49 many species, are larger than the inner teeth, and are arranged in a single regular row (e.g.,

50 Poll 1956: figs. 10, 17). The fishes of the genus Petrochromis inhabit the rocky littoral zone

51 where they represent one of the dominant cichlid genera (Sturmbauer et al. 2008; Takeuchi et

52 al. 2010; van Steenberge et al. 2011); sandy bottom between rocky habitats restricts

53 migration and gene flow in these fishes (Wagner and McCune 2009; Wagner et al. 2012).

54 Thus, their habitat fragmentation and allopatric diversification resulted in numerous local

55 colour variants (e.g., Kohda et al. 1996; Konings 1998). Six taxonomic species are currently

56 considered valid in this genus (Yamaoka 1983b; Poll 1986; Maréchal and Poll 1991): P.

57 famula Matthes and Trewavas 1960, P. fasciolatus Boulenger 1914, P. macrognathus

58 Yamaoka 1983b, P. orthognathus Matthes 1959, P. polyodon Boulenger 1898, and P.

59 trewavasae Poll 1948. Although molecular phylogenies based on mitochondrial DNA

60 (mtDNA) sequences and amplified fragment length polymorphism (AFLP) of nuclear DNA

61 question the monophyly of this genus (Sturmbauer et al. 2003; Koblmüller et al. 2010), this

62 study uses this conventional taxonomic classification. 
64 During his survey at the southern end of Lake Tanganyika, M. Hori of Kyoto University

65 found an undescribed Petrochromis fish that was similar to P. fasciolatus in body coloration

66 and stripe pattern (Fig. 2) but did not have a protruding lower jaw that characterises $P$.

67 fasciolatus (Yamaoka 1983b). This fish was first recorded in 1996 and has been called

68 Petrochromis sp. ("rotundus") (Takeuchi et al. 2010). The present study conducted

69 morphological and molecular analyses and compared the undescribed fish with the six

70 known Petrochromis species to infer whether this fish is indeed a distinct taxonomic species.

Materials and methods fish at Kasenga, Zambia (Fig. 1) by chasing the fish into a screen net while SCUBA diving. For molecular analyses, the right pectoral fin was fixed in $100 \%$ ethyl alcohol in nine of the twelve individuals. The bodies of all the individuals were fixed in $10 \%$ formalin and thereafter preserved in 70-75\% ethyl alcohol for morphological analyses.

81 Comparative materials for morphological analyses. For comparison, 130 specimens

82 including name-bearing types (i.e., holotypes and syntypes) of the six described

83 Petrochromis species were examined (Tables 1, S1).

85 Brichard (1989) divided P. trewavasae into two subspecies based on differences in body 
86 colouration and caudal-fin shape and described one of the subspecies as Petrochromis

87 trewavasae ephippium Brichard 1989. No type specimens have been designated for P. $t$.

88 ephippium. Konings (1998) reported another P. trewavasae-like fish, Petrochromis sp.

89 "Moshi Yellow". These three fishes show different geographical distributions with overlaps

90 at a few localities; Petrochromis trewavasae trewavasae is restricted to the southern region of

91 the west coast of the lake, Petrochromis sp. "Moshi Yellow" is found at several localities on

92 the east coast, and P. t. ephippium is distributed over the other coastal regions (Konings

93 1998). As the taxonomic status of these fish is still unclear, the present study treats these fish

94 as a single operational taxonomic unit, P. trewavasae, though these fish probably includes

95 some distinct species [Koblmüller et al. 2010; J. Snoeks of MRAC (Royal Museum for

96 Central Africa, Tervuren, Belgium) personal communication; SK personal observation]. The

97 present sample for morphological analyses includes three individuals that are considered (as

98 judged from their sampling locations) P. t. trewavasae, 17 individuals that are considered P. t.

99 ephippium, and two individuals that are considered Petrochromis sp. "Moshi Yellow".

101 Some phenotypic variants are known in the P. polyodon species-complex (e.g., Koblmüller et 102 al. 2010; Wagner et al. 2012). Although paraphyletic in a mtDNA-phylogeny, this

103 species-complex forms a well-supported monophyletic group based on nuclear multi-locus

104 (AFLP) data (Koblmüller et al. 2010). As the taxonomic status of these fishes is still

105 unresolved, the present study treats this species-complex as a single operational taxonomic

106 unit, P. polyodon, though it clearly represents a complex of several distinct, partially

107 sympatric species (Koblmüller et al. 2010; Wagner et al. 2012). 
109 Konings (1998) reported a local variant of $P$. orthognathus from the east coast between

110 Luagala Point and Cape Mpimbwe and called it Petrochromis sp. "orthognathus ikola".

111 Molecular phylogenies based on AFLP and mtDNA strongly support the monophyly of a

112 clade containing P. orthognathus and Petrochromis sp. "orthognathus ikola" (Koblmüller et

113 al. 2010). As the taxonomic status of Petrochromis sp. "orthognathus ikola" is still

114 unresolved, the present study treats these individuals as a single operational taxonomic unit,

115 P. orthognathus. The present morphological analysis includes 20 individuals that are

116 considered (as judged from their sampling locations) P. orthognathus and six individuals that

117 are considered Petrochromis sp. "orthognathus ikola".

119 Interochromis loocki (Poll 1949) is known among aquarists as Petrochromis sp.

120 "orthognathus tricolor", reflecting its similarities in general appearance to $P$. orthognathus

121 (Konings 1998). However, this species does not meet the morphological definition of

122 Petrochromis; for example, the outer teeth on jaws are bicuspid in I. loocki, whereas tricuspid

123 in Petrochromis. Therefore, this species is not a member of the morphologically defined

124 genus Petrochromis, and the present study did not include this species in morphological 125 analyses.

127 Morphological data. Sixteen morphometric characters [standard length (SL), body depth, 128 head length, length and depth of caudal peduncle, lengths of dorsal-fin and anal-fin bases, 129 lengths of pectoral, pelvic, and caudal fins, head width, snout length, eye length, interorbital 
130 width, lower-jaw length, and upper-jaw protrusion] and 10 meristic characters (spines and

131 soft rays in dorsal fin, spines and soft rays in anal fin, soft rays in pectoral fin, scales in

132 longitudinal line, scales on upper and lower lateral lines, scale rows between lateral lines, and

133 gill rakers on the first ceratobranchial) were examined in all individuals, and four

134 morphometric characters on the lower pharyngeal jaw (length and width of lower pharyngeal

135 jaw, and length and width of dentigerous area on the lower pharyngeal jaw) were measured in

136 one individual of the undescribed fish (MRAC B3-03-P-05). The methods used to measure

137 and count these characters correspond with those of Snoeks (2004) with the following

138 exceptions. Lengths of the pectoral and pelvic fins were measured from the base to the tip of

139 the longest ray in each fin. Length of the caudal fin was measured from the base to the tip of

140 the longest soft ray in the upper lobe, which was the second, third or fourth branched soft ray

141 from the upper. The base of the soft ray is on a skinfold resulting from lateral bending of the

142 caudal fin. Protrusion of the upper jaw is the horizontal distance between the anterior tips of

143 the upper and lower jaws when the mouth was closed completely, or closed to the

144 hypothetical normal position in species that cannot close the mouth completely. The anterior

145 tips of jaws are on the lip-tissues. When the lip-tissues have been fixed in unnatural shape,

146 the upper-jaw protrusion was measured between hypothetical points if the lip-tissues would

147 have been in natural shape. A positive value indicates that the upper jaw protrudes anterior to

148 the lower jaw and a negative value indicates that the lower jaw protrudes anterior to the upper

149 jaw. Scale rows between lateral lines were counted at the anterior end of the lower lateral

150 line. Paired characters except for gill rakers were measured or counted on the left side of the

151 body unless these were broken. Gill rakers were counted on the right side. Although counted 
152 in many taxonomic studies of cichlid fish, the outer teeth on the upper jaw were not counted

153 in the present study, as they are difficult to count correctly; these teeth were irregularly

154 arranged and not distinguishable from the inner teeth in Petrochromis. The last two soft rays

155 of the dorsal and anal fins were counted as two soft rays, although these are sometimes

156 counted as one soft ray in non-cichlid fishes (e.g., Hubbs and Lagler 2004). The numbers of

157 spines and soft rays in a fin were indicated by Roman and Arabic numerals, respectively.

159 Measurements were taken to the nearest $0.1 \mathrm{~mm}$ using dividers or digital callipers except for

160 the lower pharyngeal jaw, of which measurements were taken to the nearest $0.01 \mathrm{~mm}$ using a 161 digital microscope (KEYENCE VHX-100).

163 Statistical analyses of morphological data. Fifteen morphometric characters and eight

164 meristic characters were used for statistical analyses. The SL was used as covariate. The four

165 morphometric characters on the lower pharyngeal jaw, the number of spines on anal fin, and

166 the number of scale rows between lateral lines were not used for statistic analyses, as these

167 were measured only in one individual or were invariable.

169 Three analyses were conducted to test differences between the undescribed fish and each of

170 the six known Petrochromis species and between sexes; those were a multivariate analysis of

171 covariance (MANCOVA) with $\log _{10}$-transformed SL as a covariate on $14 \log _{10}$-transformed

172 morphometric characters except for upper jaw protrusion, an analysis of covariance

173 (ANCOVA) with SL as a covariate on the upper jaw protrusion, of which the raw data were 
174 analysed, as it can be zero or negative, and a multivariate analysis of variance (MANOVA)

175 for the eight meristic characters. Critical significance levels were corrected following the

176 Bonferroni procedure.

Phylogeny of mtDNA sequences. Koblmüller et al. (2010) inferred the phylogeny of the

Tropheini based on mtDNA sequence data, including the NADH dehydrogenase subunit 2 gene (ND2, 1047 bp) and control region (CR, 962 bp; excluding the poly-T region). To infer the phylogenetic position of the undescribed Petrochromis fish, we added mtDNA sequence data of this fish to the data matrix of Koblmüller et al. (2010) [N=9, MRAC B3-03-P-04 to

183 B3-03-P-07 and BMNH (The Natural History Museum, London, UK) 2013.2.13.1 to

184 2013.2.13.5]. We also included mtDNA sequence data of P. macrognathus, which has not 185 been included in the phylogenetic analysis of Koblmüller et al. (2010) [N=6, Zm (private 186 collection of M. Hori) 02170, 02573, 02574, 02578, 02579, 03532, collected at Kasenga, 187 Zambia]. Petrochromis polyodon, P. cf. polyodon, P. sp. "macrognathus rainbow", and P. sp.

188 "Texas Longola" of Koblmüller et al. (2010) were treated as P. polyodon, and P. trewavasae, 189 P. t. ephippium, and Petrochromis sp. "Moshi yellow" were treated as P. trewavasae (see 190 above). This phylogenetic analysis includes the undescribed fish of Petrochromis, all the six 191 described congeners, and two unidentified fishes; namely, Petrochromis sp. "Katete" and $P$. 192 cf. macrognathus (sensu Koblmüller et al. 2010). Details for the samples used in the 193 phylogenetic analysis are in Table S2. 
196 (Bio-Rad). Polymerase chain reaction was conducted using a GeneAmp PCR System 9700

197 (Applied Biosystems) with the following programme: one cycle of $94^{\circ} \mathrm{C}$ for 2 min., and 32

198 cycles of $94{ }^{\circ} \mathrm{C}$ for $15 \mathrm{~s}, 55^{\circ} \mathrm{C}$ for $30 \mathrm{~s}, 72{ }^{\circ} \mathrm{C}$ for 2 min. The ND2 region was amplified with 199 the primers MET (Duftner et al. 2005) and TRP (Kocher et al. 1995), and sequenced using 200 these primers and the internal primers ND2.T-R and ND2.2A (Duftner et al. 2005). The CR 201 was amplified with the primers L-Pro-F_Tropheus (Koblmüller et al. 2011) and TDK-DHG 202 (primer G in Lee et al. 1995), and sequenced using these primers and the internal primers 203 TDK-D (primer E in Lee et al. 1995) and SC-DL (Salzburger et al. 2002). The PCR 204 fragments were purified using PEG and directly sequenced with the BigDye sequencing 205 chemistry (Applied Biosystems) using an ABI 3130xl sequencer (Applied Biosystems). 206 DNA sequences were aligned by eye using MEGA4 software (Tamura et al. 2007).

207 Sequences are available in the DNA Data Bank of Japan (DDBJ Accession no. AB850665208 AB850679 for ND2, AB850680-AB850694 for CR).

210 Phylogenetic tree construction. Phylogenetic inference based on maximum-likelihood (ML)

211 was done in Treefinder version October 2008 (Jobb et al. 2004). Shotgun search was repeated 212 until the likelihood value was not improved. Statistical support was assessed by 213 bootstrapping (100 pseudo-replicates). The best-fit model of molecular evolution for each 214 region was selected under the Akaike Information Criterion (AIC) by Kakusan4 (Tanabe 215 2011). The transition model (TIM) with gamma distribution (+ G) was selected for the first 216 and second codon positions of the ND2 region, and the J2 model + G for the third position. 217 The general time reversible model (GTR) + G was selected for the CR. Bayesian 
218 phylogenetic analysis was conducted using MrBayes version 3.2 (Ronquist and Huelsenbeck

219 2003). Data were partitioned by gene, and additionally by codon position within ND2. Rate

220 heterogeneity was set according to a gamma distribution with six rate categories (GTR

221 model) for each data partition, which was selected under the AIC by Kakusan4. Posterior

222 probabilities were obtained from MCMC simulations (5 million generations; trees sampled

223 every 100 generations). The first 2000 trees were discarded as burn-in to obtain 50\% majority

224 consensus topology. Chain stationarity was checked using Tracer version 1.5 (Rambaut and

225 Drummond 2009).

226

227

228

Results

229

230

Morphological analyses. Raw morphometric and meristic data for the undescribed fish and

231 the six known Petrochromis species are available in Table S1. The ranges of some characters

232 did not or little overlap between the undescribed fish and the known species (Table 2).

233

234 The MANCOVAs on $14 \log _{10}$-transformed morphometric characters showed significant

235 differences between the undescribed fish and five known Petrochromis species except for $P$.

236 polyodon (Table 3). Petrochromis polyodon was not significantly different from the

237 undescribed fish in these characters after a Bonferroni correction, but the $P$-value was rather

238 small (0.0096). The range of upper-jaw protrusion of the undescribed fish did not overlap

239 with those of P. fasciolatus, P. macrognathus, P. polyodon, and P. trewavasae (Table 2), and 
240 these differences were statistically significant (Table 3). The MANOVAs on eight meristic

241 characters showed significant differences between the undescribed fish and five known

242 species except for $P$. fasciolatus (Table 3). Sexual differences were not significant in these 243 analyses.

245 Phylogenetic analysis of mtDNA sequences. Except for some nodes with bootstrap support

246 (BS) lower than 70 of the ML tree, the ML and Bayesian tree topologies were identical (Fig.

247 3). Both analyses resolved the undescribed fish as a monophyletic group (BS of 100), sister

248 to Petrochromis sp. "Katete" (BS of 100), which together represent a rather distinct clade of

249 the genus Petrochromis. Petrochromis macrognathus resulted as monophyletic and was

250 placed in a lineage containing the polyphyletic species $P$. polyodon and $P$. trewavasae. The

251 other parts of the trees were identical with the mtDNA tree of Koblmüller et al. (2010) except

252 for nodes with low bootstrap support; i.e. the monophyly of each species and Tropheus

253 species complex was recovered with high bootstrap support with exception of $P$. polyodon

254 and P. trewavasae. All polytypic genera (Petrochromis, Simochromis Boulenger 1898, and

255 Tropheus Boulenger 1898) resulted as polyphyletic.

\section{Discussion}

259

260 Taxonomy. The undescribed fish was clearly distinct from the six described species of the 261 genus Petrochromis in several morphological characters with no or less overlaps (Table 2). 
262 These morphological differences were statistically significant (Table 3). The ML and

263 Bayesian trees based on mtDNA sequences showed a clear separation of the undescribed fish

264 from the six congeners (Fig. 3). Thus, both morphological and molecular data support the

265 hypothesis that the undescribed fish represents a distinct taxonomic species rather than a

266 variant of a described species of Petrochromis.

267

Habitat use. The undescribed fish occurs sympatrically with five known species of

269 Petrochromis except for P. orthognathus at Kasenga (i.e., P. famula, P. fasciolatus, $P$. macrognathus, P. polyodon, and P. trewavasae). The undescribed fish is usually found on

271 rocks at 13-15 m depth (main habitat of this fish may be deeper than this area). The five sympatric congeners mainly dwell in shallower areas, and their densities are much lower in

273 the deep-water areas where the undescribed fish occurs [present study; appendix S2 of

274 Takeuchi et al. (2010), which called the undescribed fish Petrochromis sp. ("rotundus")]. The 275 undescribed fish may reduce congeneric competition for resources such as food by exploiting 276 this deep habitat.

278 Phylogenetic considerations. Although phylogenetic inference of Lake Tanganyika's 279 cichlids, including the Tropheini, based on mtDNA data has been repeatedly shown to be 280 heavily impacted by (ancient) incomplete lineage sorting and (ancient)

281 hybridisation/introgression (e.g., Rüber et al. 2001; Koblmüller et al. 2007ab, 2010;

282 Sturmbauer et al. 2010), mtDNA data do provide important information on phylogenetic 283 relationships between species. The close phylogenetic relationship of the undescribed 
284 Petrochromis species with $P$. sp. "Katete" might indicate that these two taxa are conspecific.

285 Unfortunately, no voucher specimen is available for $P$. sp. "Katete", but it resembles the

286 undescribed fish in its overall appearance (SK personal observation). Similarly,

287 Petrochromis sp. "flame tail", another deep-water Petrochromis that recently entered the 288 aquarium trade resembles the undescribed fish. More samples and analyses are needed to 289 clarify whether these fish belong to the same taxonomic species as the undescribed fish and 290 what's the geographic distribution of this species.

The new mtDNA data, in particular those of $P$. macrognathus, indicate that the large-bodied P. polyodon-, P. macrognathus- and P. trewavasae-like fishes are very closely related. Paraphyly or polyphyly of nominal taxa may indicate that incomplete lineage sorting and/or hybridization complicate phylogenetic inference and taxonomic assignment based on single 296 molecular markers in this cichlid lineage (also see Sturmbauer et al. 2003; Koblmüller et al. 297 2010). Nevertheless, the mtDNA data point to the urgent need for an extensive taxonomic 298 revision of the entire genus as morphologically and genetically distinct, yet taxonomically 299 undescribed, taxa of the P. polyodon-species complex appear to occur sympatrically at 300 various locations (Konings 1998; Koblmüller et al. 2010; Wagner et al. 2012). Thus, at 301 present the true species number and consequently diversification rate appears to be 302 dramatically underestimated in this clade, similar to the situation in the closely related genus 303 Tropheus (Konings 1998; Schupke 2003; Egger et al. 2007). 
306

307

308

309

310

311

312

313

314

315

316

\section{Petrochromis horii n. sp.}

Here the undescribed fish is named Petrochromis horii n. sp.

Holotype. MRAC B3-03-P-01 (female, 137.6 mm SL), Kasenga, Zambia, rocky bottom at 13 m depth, screen net, M. Hori and T. Takahashi, 21 Nov. 2009.

Paratypes. $N=11$. A fin-clip was taken from nine specimens for DNA analysis (indicated by *). MRAC B3-03-P-02 (female, 85.0 mm SL), B3-03-P-03 (female, 105.7 mm SL), B3-03-P-04* (male, 100.7 mm SL), collected with the holotype; MRAC B3-03-P-05* (female, 128.3 mm SL), Kasenga, Zambia, rocky bottom at 15 m depth, screen net, M. Hori, 28 Nov. 2007; MRAC B3-03-P-06* (female, 116.6 mm SL), B3-03-P-07* (female, 100.4 mm SL), Kasenga, Zambia, rocky bottom at 14 m depth, screen net, M. Hori, 5 Nov. 2008; BMNH 2013.2.13.1* (male, 104.4 mm SL), 2013.2.13.2* (male, 100.1 mm SL), 2013.2.13.3* (female, 130.3 mm SL), 2013.2.13.4* (male, 89.1 mm SL), 2013.2.13.5* (female, 105.7 mm SL), Kasenga, Zambia, rocky bottom at 14 m depth, screen net, M. Hori, 9 Nov. 2008.

Diagnosis. This new taxonomic species differs from its congeners with no overlaps in several morphological characters (Table 2). Its body is deeper than that of P. macrognathus, the caudal peduncle is deeper than that of $P$. orthognathus, the pectoral fin is longer than that of $P$. macrognathus, the pelvic fin is longer than that of $P$. fasciolatus, the caudal fin is longer 
328 than that of $P$. famula, $P$. fasciolatus, and P. orthognathus, the interorbital region is wider than

329 that of P. macrognathus and $P$. orthognathus, the upper jaw protrudes more than that of $P$.

330 fasciolatus and less than that of P. macrognathus, P. polyodon, and P. trewavasae, the soft

331 rays in the dorsal fin are fewer than in P. macrognathus, and the number of scales in

332 longitudinal line is larger than in P. famula and P. orthognathus.

333

334 Morphological description. The morphological description, except for the lower

335 pharyngeal jaw, is based on the holotype (Fig. 4a, b), and the ranges for paratypes are given

336 in parentheses; the morphometric and meristic data are summarized in Table 4. The

337 description of the lower pharyngeal jaw is based on a paratype (MRAC B3-03-P-05, Fig. 4c).

339 Body short, deepest at dorsal-fin origin, gradually becoming shallow to caudal peduncle;

340 caudal peduncle short, depth of caudal peduncle 89.2\% (82.2-101.6\%) of its length. Dorsal

341 profile of head sloping steeply; ventral profile slightly rounded. Eye small, rounded

342 [percentage of eye length against head length decreased with increasing SL, non-parametric

343 Spearman test: $N=12$ (holotype and 11 paratypes), $\rho=-0.73, P=0.007$ ]; eye length $62.4 \%$

344 (62.2-72.8\%) of snout length. Interorbital region convex. Mouth lower than body axis; jaws

345 almost equal anteriorly [percentage of upper jaw protrusion against head length decreased

346 with increasing SL, non-parametric Spearman test: $N=12$ (holotype and 11 paratypes), $\rho=$

$347-0.84, P<0.001$ ]; posterior edge of mouth not reaching vertical line through anterior margin 348 of eye. 
350 Dorsal fin originating slightly anterior to vertical line through posterior margin of operculum;

351 each spine with a lappet near tip; all soft rays branched; posterior tip of the fin elongate,

352 extending beyond caudal-fin base when depressed. Anal fin originating slightly anterior to

353 vertical line through base of last dorsal-fin spine; three spines increasing in length

354 posteriorly; first and second spines with a lappet near tip; all soft rays branched; posterior tip

355 elongate, extending beyond caudal-fin base when depressed. Upper end of pectoral-fin base

356 slightly posterior to vertical line through posterior margin of operculum; distal tip acutely

357 pointed; fifth soft ray from upper longest, reaching vertical line through anus; soft rays

358 branched, except uppermost two and lowermost two (except uppermost two and lowermost

359 one or two). Pelvic fin originating posterior to vertical line through posterior margin of

360 operculum; all soft rays branched; outer soft rays longer than inner ones; outermost soft ray

361 filamentous, reaching anal-fin origin. Caudal fin lunate; distal tips of upper and lower lobes 362 acutely pointed.

364 Scales on flank cycloid or ctenoid with radially directed short ctenii; granulation extending 365 over almost entire exposed part of scale. Posterior half of cheek scaled; caudal fin with scales 366 on fin membrane between rays; other fins lack scales. Upper lateral line originating from 367 sensory canal of supracleithrum, running below dorsal margin of body, posteriorly not 368 reaching posterior end of dorsal-fin base. Lower lateral line running on body axis, anteriorly 369 not reaching vertical line through anal-fin origin, posteriorly extending beyond caudal-fin 370 base. 
372 Oral teeth tricuspid, arranged in 9 to 11 irregular rows at anterior parts of upper and lower

373 jaws, making brush-like, broad tooth plate on each jaw; outer and inner teeth

374 indistinguishable in size, shape, or arrangement pattern. Gill rakers short.

375

376 Lower pharyngeal jaw of a paratype (MRAC B3-03-P-05, Fig. 4c) sub-triangular with

377 concave lateral margins and roundly convex caudal margins on both sides, length $14.83 \mathrm{~mm}$,

378 width $12.63 \mathrm{~mm}$; dentigerous area sub-triangular, length $6.80 \mathrm{~mm}$, width $10.13 \mathrm{~mm}$; teeth

379 villiform.

380

381 Body colour pattern. The colour of live fish is described based on two photographs; one is

382 of the holotype that was taken under water when it was caught (Fig. 4b, female), and the other

383 is of individuals that were not collected (Fig. 2b, sex unknown). A part of head anterior to the

384 posterior margin of eye moss green; pale ventrally. Body with eleven moss green vertical

385 bands from nape to caudal-fin base (the most anterior one combines with the moss-green blot

386 on the head in Fig. 4b), and a moss green or dark green horizontal broad band on body axis

387 (pale above anus, breaking the band into two parts in Fig. 2b); spaces between the bands and

388 ventral part of body pale green. Fins moss green; anterior margin of pelvic fin pale green.

390 The vertical and horizontal bands are unclear in fixed specimens (Fig. 4a).

391

392 Sexual dimorphism. Apparent differences between sexes were not found in morphometric

393 and meristic characters. The largest female was 1.3 times larger than the largest male in SL, 
394 but small sample size precludes a definite conclusion (note: males grow larger than females

395 in all other species of Petrochromis). Given the relatively small size of the males examined,

396 no sexual dimorphism of body shape and coloration was observed. Whether P. horii n. sp.

397 indeed exhibits no (or even reversed) sexual dimorphism in body shape, coloration, or body

398 size clearly requires the examination of a larger sample size of adult specimens.

399

400 Distribution. At present, this new species is only known from Kasenga.

401

402 Etymology. Named in honour of M. Hori of Kyoto University, Japan; he suggested that this 403 fish might represent an undescribed species.

406 Key to the seven Petrochromis species.

408 This key was constructed based on specimens larger than $\sim 80 \mathrm{~mm}$ SL (Table 2). Therefore, 409 the key morphometric characters are not applicable to smaller individuals. Known maximum 410 SL of each species was drawn from Poll (1956), Yamaoka (1983b), and the present study.

412 1a. Lower jaw protruding anterior to upper jaw (protrusion of upper jaw -1.0 to $-6.6 \%$ of head length, Fig. 5a) ---------- P. fasciolatus (maximum SL, 131.0 mm)

414 1b. Upper jaw a little protruding anterior to lower jaw (protrusion of upper jaw 0.6-4.6\% of head length, Fig. 5b) ---------- 2 
416 1c. Upper jaw greatly protruding anterior to lower jaw (protrusion of upper jaw 4.8-15.4\% of head length, Fig. 5c) $-4$

2a. 34 or 35 scales in longitudinal line; caudal fin long (length $27.2-32.3 \%$ of SL) $P$. horii n. sp. (maximum SL, $137.6 \mathrm{~mm}$ )

2b. 31-33 scales in longitudinal line; caudal fin short (length 22.2-26.3\% of SL) ---------- 3

3a. Body shallow (depth 36.5-41.5\% of SL); head small (length 30.5-33.7\% of SL); caudal

3b. Body deep (depth 40.5-45.0\% of SL); head large (length 31.9-36.3\% of SL); caudal peduncle deep (depth 79.4-108.2\% of the length); usually 8 soft rays in anal fin peduncle narrow (depth 71.4-88.9\% of the length); 7 soft rays in anal fin ---------- $P$. orthognathus (maximum SL, 150.5 mm) P. famula (maximum SL, $133.0 \mathrm{~mm}$ )

4a. 11 or 12 soft rays in dorsal fin; interorbital region narrow (width $28.8-33.9 \%$ of head length); upper jaw protrusion 6.4-15.4\% of head length; pectoral fin short (length 24.130.1\% of SL) ---------- P. macrognathus (maximum SL, $178.7 \mathrm{~mm}$ )

4b. Usually 10 or less soft rays in dorsal fin; interorbital region wide (width $31.2-40.9 \%$ of

5a. Usually 17 or 18 spines in dorsal fin; usually 8 soft rays in anal fin; caudal fin short (maximum SL, $179.8 \mathrm{~mm}$ )

5b. Usually 19 spines in dorsal fin; usually 7 soft rays in anal fin; caudal fin long (length 28.3-35.8\% of SL); dorsal profile of head nearly straight P. trewavasae 
(maximum SL, $153.3 \mathrm{~mm}$ )

441 Acknowledgements We thank M. Hori for providing specimens; P. Ngalande, H. Phiri, D.

442 Sinyinza and other staff of Department of Fisheries, the Ministry of Livestock and Fisheries, 443 Zambia and B. Ngatunga, A. Chande and other staff of Tanzania Fisheries Research Institute 444 for their support in the field; J. Snoeks, R. Britz, M. Yabe, Y. Kai, G. Shinohara, Y. Terai, and

445 H. Hata for their assistance during the examination of comparative specimens; J. Snoeks and 446 R. Britz for depositing type specimens of P. horii n. sp. in MRAC and BMNH, respectively; 447 J. Snoeks for comments on the taxonomic status of P. t. ephippium; and Y. Kai for measuring 448 the upper-jaw protrusion in some specimens. This study was supported by Grants-in-Aid for 449 Special Purposes (No. 18779002), Young Scientists (B) (No. 20770065), and Scientific 450 Research (B) (No. 23370043) from the Ministry of Education, Culture, Sports, Science and 451 Technology, Japan.

\section{References}

Boulenger GA (1898) Report on the fishes recently obtained by Mr. J. E. S. Moore in Lake Tanganyika. Proc Zool Soc Lond :494-497

Boulenger GA (1914) Diagnoses des poissons nouveaux: I. Acanthoptérygiens, Opisthomes, 
460 Brichard P (1989) Cichlids and all the other fishes of Lake Tanganyika. T.F.H. Publications, $461 \quad$ Neptune City

462 Burgess WE (2012) A new species of goby cichlid of the genus Eretmodus, E. marksmithi, 463 (Pisces: Cichlidae) from the northern part of Lake Tanganyika. Tanganika Mag 12:2331

Cohen AS, Soreghan MJ, Scholz CA (1993) Estimating the age of formation of lakes: an

Coulter GW (1994) Lake Tanganyika. Adv Limnol 44:13-18

Duftner N, Koblmüller S, Sturmbauer C (2005) Evolutionary relationships of the Limnochromini, a Tribe of benthic deepwater cichlid fish endemic to Lake Tanganyika, East Africa. J Mol Evol 60:277-289

Fryer G, Iles TD (1972) The cichlid fishes of the great lakes of Africa. T.F.H. Publications, Neptune City

Gante HF, Salzburger W (2012) Evolution: Cichlid models on the runaway to speciation. Current Biol 22:R956-958

Günther A (1893) Descriptions of the reptiles and fishes collected by Mr. E. Coode-Hore on Lake Tanganyika. Proc Zool Soc Lond 628-632.

Hubbs CL, Lagler KF (2004) Fishes of the great lakes region, revised edition, revised by 
482 Iles RB (1960) A group of zooplankton feeders of the genus Haplochromis (Cichlidae) in 483 Lake Nyasa. Ann Mag Nat Hist (13) 2:257-280

484 Jobb G, von Haeseler A, Strimmer K (2004) TREEFINDER: a powerful graphical analysis 485 environment for molecular phylogenetics. BMC Evol Biol 4:18

Koblmüller S, Duftner N, Sefc KM, Aibara M, Stipacek M, Blanc M, Egger B, Sturmbauer C (2007a) Reticulate phylogeny of gastropod-shell-breeding cichlids from Lake Tanganyika - the result of repeated introgressive hybridization. BMC Evol Biol 7:7

Koblmüller S, Egger B, Sefc KM, Sturmbauer C (2007b) Evolutionary history of Lake Tanganyika’s scale-eating cichlid fishes. Mol Phylogenet Evol 44:1295-1305

491 Koblmüller S, Sefc KM, Sturmbauer C (2008a) The Lake Tanganyika cichlid species assemblage: recent advances in molecular phylogenetics. Hydrobiologia 615:5-20

Koblmüller S, Schliewen UK, Duftner N, Sefc KM, Katango C, Sturmbauer C (2008b) Age

Koblmüller S, Egger B, Sturmbauer C, Sefc KM (2010) Rapid radiation, ancient incomplete lineage sorting and ancient hybridization in the endemic Lake Tanganyika cichlid tribe

Koblmüller S, Salzburger W, Obermüller B, Eigner E, Sturmbauer C, Sefc K (2011) Separated by sand, fused by dropping water: habitat barriers and fluctuating water levels steer the evolution of rock-dwelling cichlid populations in Lake Tanganyika. Mol Ecol Tropheini. Mol Phylogenet Evol 55:318-334 and spread of the haplochromine cichlid fishes in Africa. Mol Phylogenet Evol 49:153169 
Nature Rev Gen 5:288-298

\section{5}

506

507

508

509

510

511

512

Kocher TD, Conroy JA, McKaye KR, Stauffer JR, Lockwood SF (1995) Evolution of NADH dehydrogenase subunit 2 in east African cichlid fish. Mol Phylogenet Evol 4:420-432

Kohda M, Yanagisawa Y, Sato T, Nakaya K, Niimura Y, Matsumoto K, Ochi H (1996) Geographical colour variation in cichlid fishes at the southern end of Lake Tanganyika. Environ Biol Fish 45:237-248

Konings A (1998) Tanganyika cichlids in their natural habitat. Cichlid Press, El Paso

Kornfield I, Smith PF (2000) African cichlid fishes: model systems for evolutionary biology. Ann Rev Ecol Syst 31:163-196

Kullander SO, Karlsson M, Karlsson M (2012) Lepidiolamprologus kamambae, a new species of cichlid fish (Teleostei: Cichlidae) from Lake Tanganyika. Zootaxa 3492:3048

Lee W-J, Conroy J, Howell WH, Kocher TD (1995) Structure and evolution of teleost mitochondrial control regions. J Mol Evol 41:54-66

Maréchal C, Poll M (1991) Petrochromis. In: Daget J, Gosse J-P, Teugels GG, Thys van den Audenaerde DFE (eds) Check-list of the freshwater fishes of Africa CLOFFA 4. ISNB, Bruxelles, MRAC, Tervuren, ORSTOM, Paris, pp. 369-373

Matthes H (1959) Un Cichlidae nouveau du lac Tanganika: Petrochromis orthognathus n. sp. Rev Zool Botanique Afr 60:335-341

Matthes H, Trewavas E (1960) Petrochromis famula n. sp. a cichlid fish of Lake Tanganyika. Rev Zool Botanique Afr 61:349-357

Poll M (1948) Description de Cichlidae nouveaux recueillis par la mission hydrobiologique 
belge au lac Tanganika (1946-1947). Bull Mus R Hist Nat Belg 24:1-31

Poll M (1949) Deuxième série de Cichlidae nouveaux recueillis par la mission

Poll M (1956) Poissons Cichlidae. Rés Sci Eplor Hydrobiol Lac Tanganika Inst R Sci Nat Belg 3(5B):1-619

Poll M (1986) Classification des Cichlidae du lac Tanganika. Tribus, genres et espèces. Acad

Rambaut A, Drummond AJ (2009) Tracer version 1.5. Available at R Belg Mém Cl Sci 45:1-163

Ronquist F, Huelsenbeck JP (2003) MrBayes 3: Bayesian phylogenetic inference under mixed models. Bioinformatics 19:1572-1574

Rüber L, Meyer A, Sturmbauer C, Verheyen E (2001) Population structure in two sympatric

Salzburger W (2009) The interaction of sexually and naturally selected traits in the adaptive radiations of cichlid fishes. Mol Ecol 18:169-185

Salzburger W, Meyer A, Baric S, Verheyen E, Sturmbauer C (2002) Phylogeny of the Lake Tanganyika cichlid species flock and its relationship to the Central and East African haplochromine cichlid fish faunas. Syst Biol 51:113-135

545 Salzburger W, Mack T, Verheyen E, Meyer A (2005) Out of Tanganyika: genesis, explosive 546 speciation, key-innovations and phylogeography of the haplochromine cichlid fishes. 
548 Schelly R, Takahashi T, Bills R, Hori M (2007) The first case of aggressive mimicry among

549 lamprologines in a new species of Lepidiolamprologus (Perciformes: Cichlidae) from

$550 \quad$ Lake Tanganyika. Zootaxa 1638:39-49

551 Schupke P (2003) Aqualog: African cichlids II, Tanganyika I, Tropheus. Verlag A.C.S.

$552 \quad$ Gmbh, Rodgau

553 Seehausen O (2006) African cichlid fish: a model system in adaptive radiation research. Proc

Snoeks J (2000) How well known is the ichthyodiversity of the large East African lakes? Adv Ecol Res 31:17-38

Snoeks J (2004) Material and methods. In: Snoeks J (ed) The cichlid diversity of Lake

Sturmbauer C, Hainz U, Baric S, Verheyen E, Salzburger W (2003) Evolution of the tribe Tropheini from Lake Tanganyika: synchronized explosive speciation producing

563 Sturmbauer C, Fuchs C, Harb G, Damm E, Duftner N, Maderbacher M, Koch M, Koblmüller S (2008) Abundance, distribution, and territory areas of rock-dwelling Lake Tanganyika

Sturmbauer C, Salzburger W, Duftner N, Schelly R, Koblmüller S (2010) Evolutionary history of the Lake Tanganyika cichlid tribe Lamprologini (Teleostei: Perciformes) derived from mitochondrial and nuclear DNA data. Mol Phylogenet Evol 57:266-284

Sturmbauer C, Husemann M, Danley PD (2011) Explosive speciation and adaptive radiation 
of East African cichlid fishes. Biodiversity Hotspots 2011:333-362

571 Takahashi T (2003) Systematics of Tanganyikan cichlid fishes (Teleostei: Perciformes).

$572 \quad$ Ichthyol Res 50:367-382

573 Takahashi T (2008) Description of a new cichlid fish species of the genus Benthochromis

574 (Perciformes: Cichlidae) from Lake Tanganyika. J Fish Biol 72:603-613

575 Takahashi T, Hori M (2006) Description of a new Lake Tanganyikan cichlid fish of the genus

576 Cyprichromis (Perciformes: Cichlidae) with a note on sexual dimorphism. J Fish Biol

577 68(B):174-192

578 Takahashi T, Koblmüller S (2011) The adaptive radiation of cichlid fish in Lake Tanganyika:

579 a morphological perspective. Int J Evol Biol 2011:Article ID 620754

580 Takeuchi Y, Ochi H, Kohda M, Sinyinza D, Hori M (2010) A 20-year census of a rocky

581 littoral fish community in Lake Tanganyika. Ecol Freshwater Fish 2010:239-248

582 Tamura K, Dudley J, Nei M, Kumar S (2007) MEGA4: molecular evolutionary genetics

583 analysis (MEGA) software version 4.0. Mol Biol Evol 24:1596-1599

584 Tanabe AS (2011) Kakusan4 and Aminosan: two programs for comparing nonpartitioned,

585 proportional and separate models for combined molecular phylogenetic analyses of

586 multilocus sequence data. Mol Ecol Res 11:914-921

587 Turner GF (2007) Adaptive radiation of cichlid fish. Current Biol 17:R827-R831

588 Turner GF, Seehausen O, Knight ME, Allender CJ, Robinson RL (2001) How many species

589 of cichlid fishes are there in African lakes? Mol Ecol 10:793-806

590 Van Steenberge M, Vanhove MPM, Muzumani RD, Mulimbwa NT, Muterezi BF, Pariselle

591 A, Gillardin C, Vreven E, Raeymakers JAM, Huyse T, Volckaert FAM, Nshombo MV, 
Snoeks J (2011) A recent inventory of the fishes of the north-western and central western coast of Lake Tanganyika (Democratic Republic Congo). Acta Ichthyol Piscat $41: 201-214$

595 Verburg P, Bills R (2007) Two new sympatric species of Neolamprologus (Teleostei:

596 Cichlidae) from Lake Tanganyika, East Africa. Zootaxa 1612:25-44

597 Wagner CE, McCune AR (2009) Contrasting patterns of spatial genetic structure in

598 sympatric rock-dwelling cichlid fishes. Evolution 63:1312-1326

599 Wagner CE, McCune AR, Lovette IJ (2012) Recent speciation between sympatric

$600 \quad$ Tanganyikan cichlid colour morphs. Mol Ecol 21:3283-3292

601 Yamaoka K (1983a) Feeding behavior and dental morphology of algae scraping cichlids (Pisces: Teleostei) in Lake Tanganyika. Afr Stud Monogr 4:77-89

Yamaoka K (1983b) A revision of the cichlid fish genus Petrochromis from Lake 
606

607

608

609

610

611

612

613

614

615

616

\section{Figure legends}

Fig. 1 Map of Lake Tanganyika $\left(29^{\circ} 05^{\prime}-31^{\circ} 15^{\prime} \mathrm{E}, 3^{\circ} 30^{\prime}-8^{\circ} 50\right.$ 'S, $650 \mathrm{~km}$ in length, Coulter 1994), showing the sampling localities of the specimens examined in morphological analyses.

Fig. 2 Underwater photographs taken at Kasenga (14-16 m depth) in November 2010 by M. Hori. Colour was corrected using Adobe Photoshop CS3 (Adobe Systems, Inc.). a The head of the group is Petrochromis fasciolatus, followed by two individuals of the undescribed fish (sex is unknown). The smallest individual could not be identified to species level. b An expanded image showing the two individuals of the undescribed fish. c Another photograph of $P$. fasciolatus; this individual appears to be a mouth-brooding female.

Fig. 3 The best ML tree of the Tropheini based on the complete ND2 gene and the mitochondrial control region (excluding the poly-T region). Only ML-bootstrap percentages $>50$ and posterior probabilities $>0.50$ resulting from Bayesian inference are shown at the nodes. Astatotilapia burtoni (Günther 1893), Aulonocara sp. and Copadichromis borleyi (Iles 1960) were used as outgroup taxa. The coloured bars depict the assignment to different genera of Tropheini. The catalogue numbers of specimens correspond to those in Table S1 and those of Koblmüller et al. (2010). Generic allocation has not been resolved for Chromis horei and Paratilapia pfefferi, so the genus in original description is tentatively used.

Fig. 4 Petrochromis horii n. sp. a Holotype (MRAC B3-03-P-01, female, 137.6 mm SL) after 
629 fixation. b Holotype when caught; colour was corrected using Photoshop; white mesh on the

630 fish is a screen net. c Lower pharyngeal jaw (14.83 mm in length) of a paratype (MRAC

631 B3-03-P-05, female, $128.3 \mathrm{~mm} \mathrm{SL}$ ) in dorsal view; the background was trimmed using

632 Photoshop.

633

634 Fig. 5 Different mouth shapes of Petrochromis. a Lower jaw protruding (P. fasciolatus, Zm

635 401-b, female, 113.1 mm SL). b Upper jaw a little protruding ( $P$. famula, Zm 869-b, female

$636108.2 \mathrm{~mm}$ SL). c Upper jaw greatly protruding (P. trewavasae, TT 1215, male, $113.0 \mathrm{~mm}$

637 SL). 


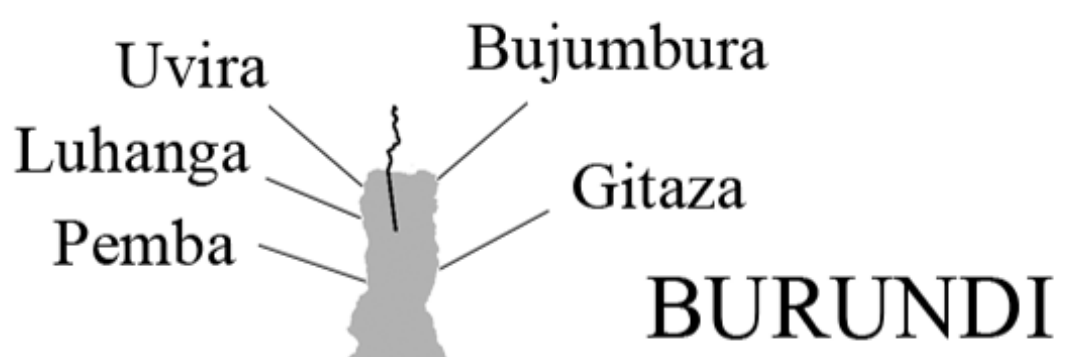

Cape Muzimu

Ubwari Peninsula
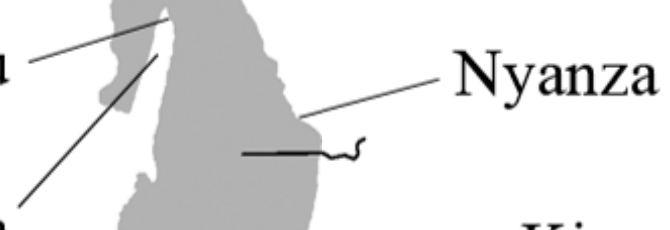

Kigoma

Kabimba

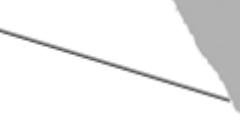

Masaka Point

Kiti Point

\section{TANZANIA}

Kalemie

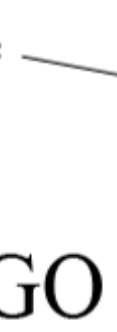

D. R. CONGO

Luagala Point

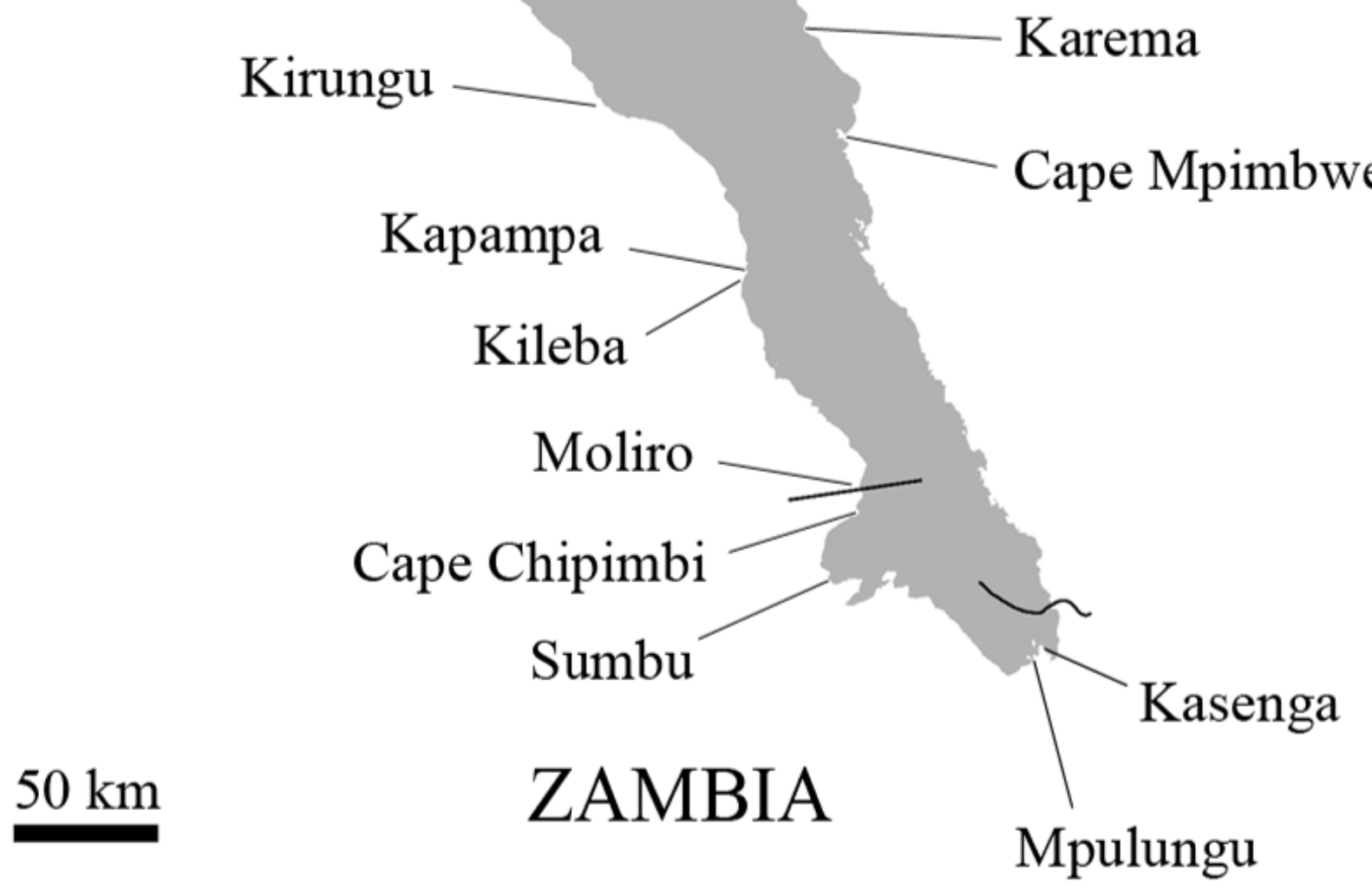

Fig. 1 

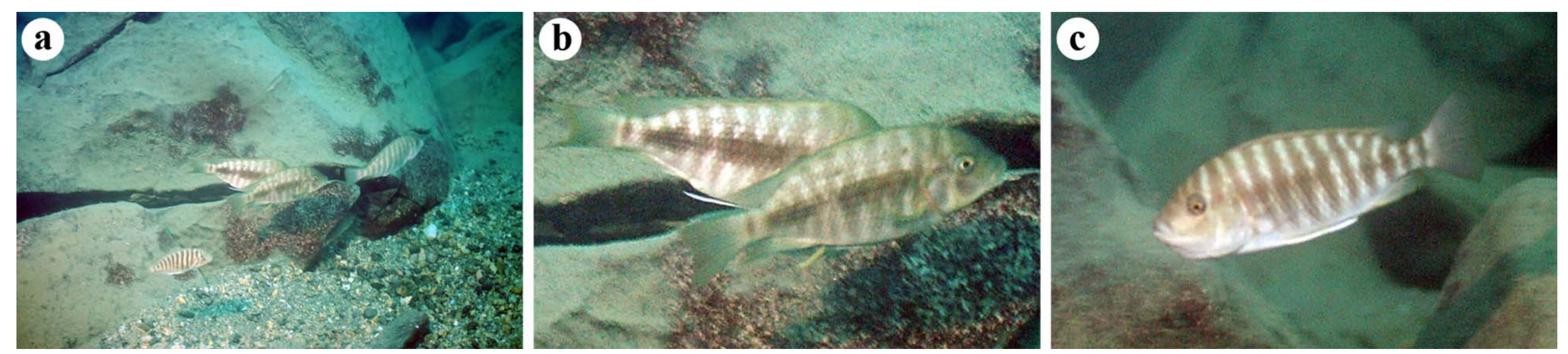

Fig. 2 


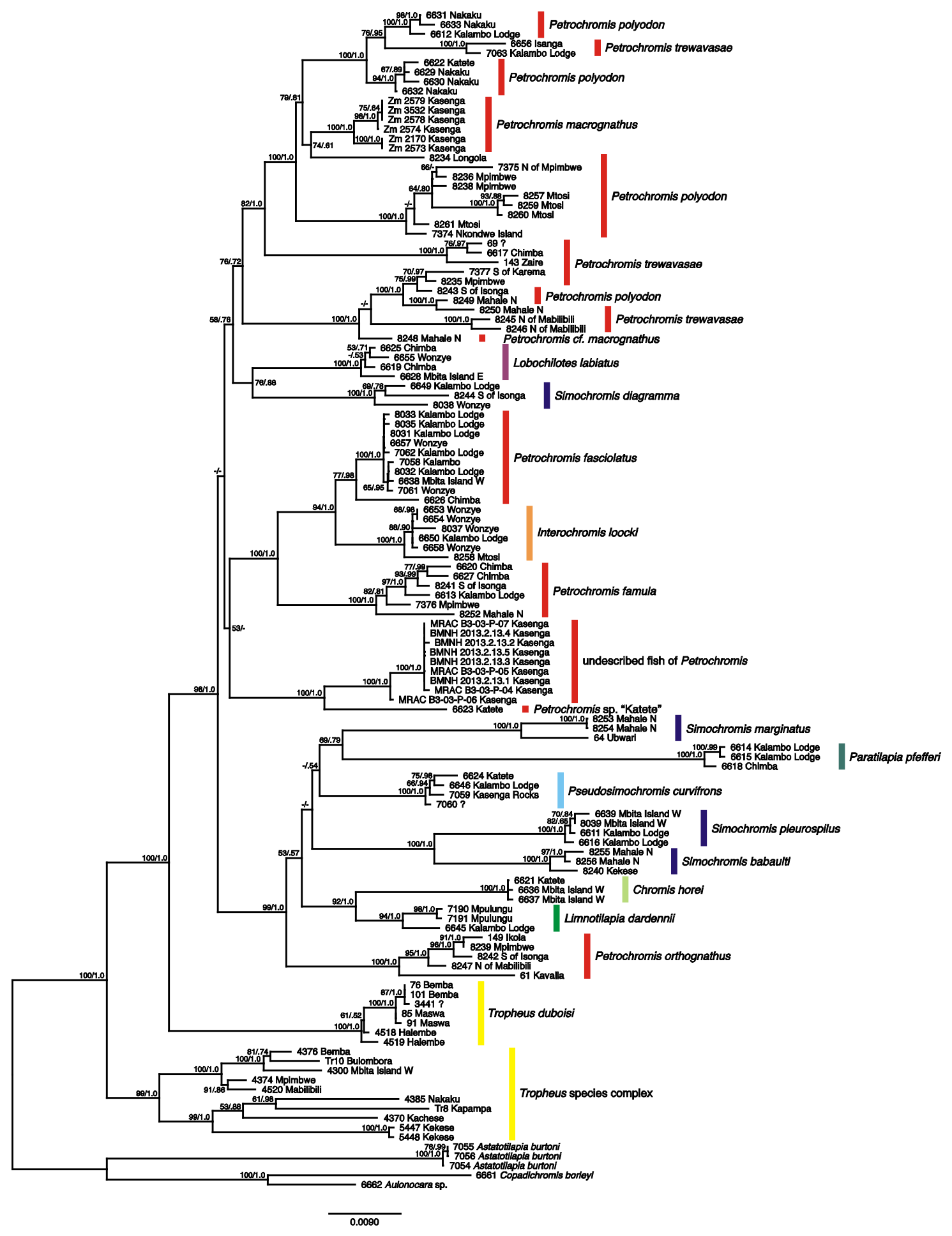

Fig. 3 


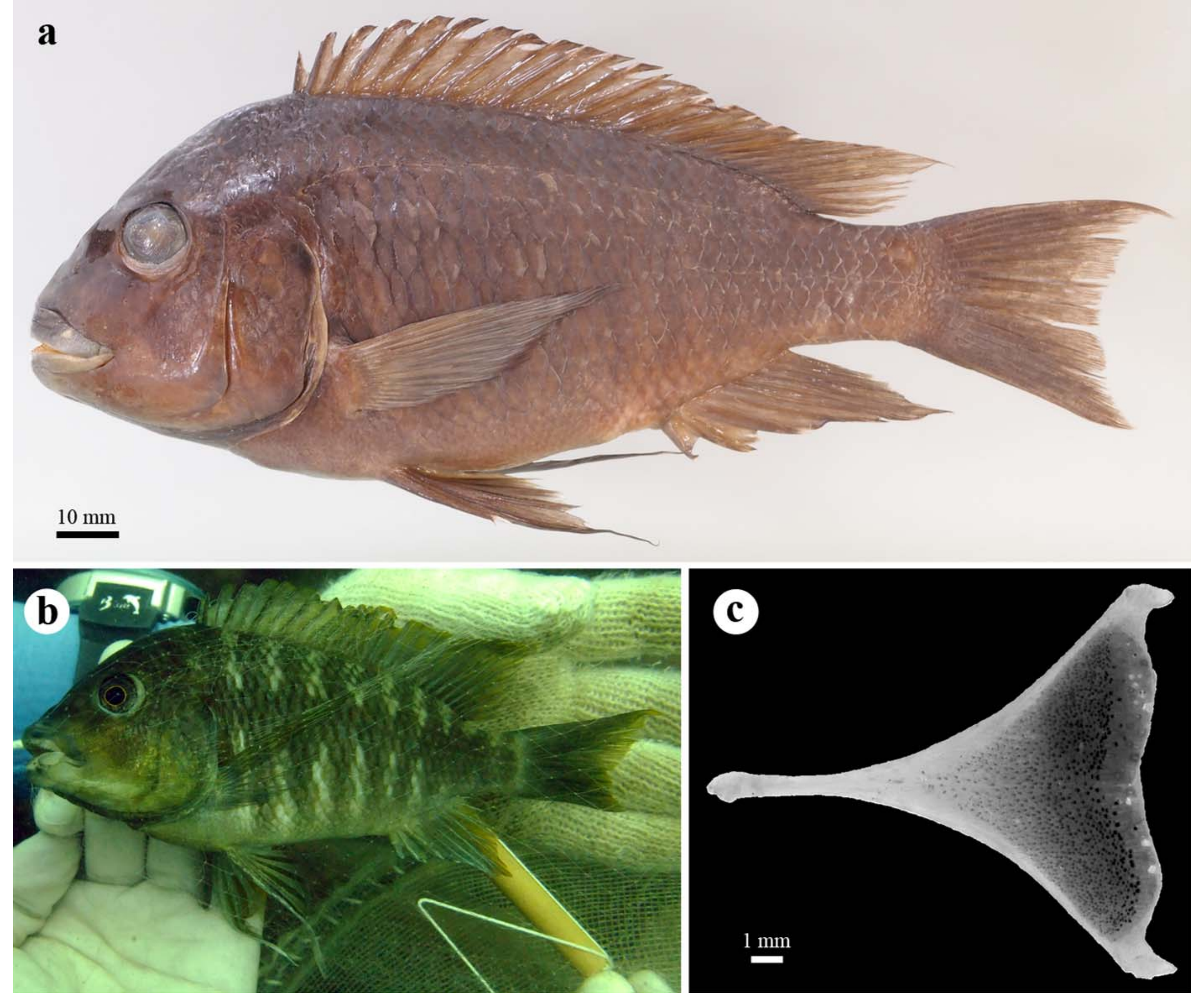

Fig. 4 


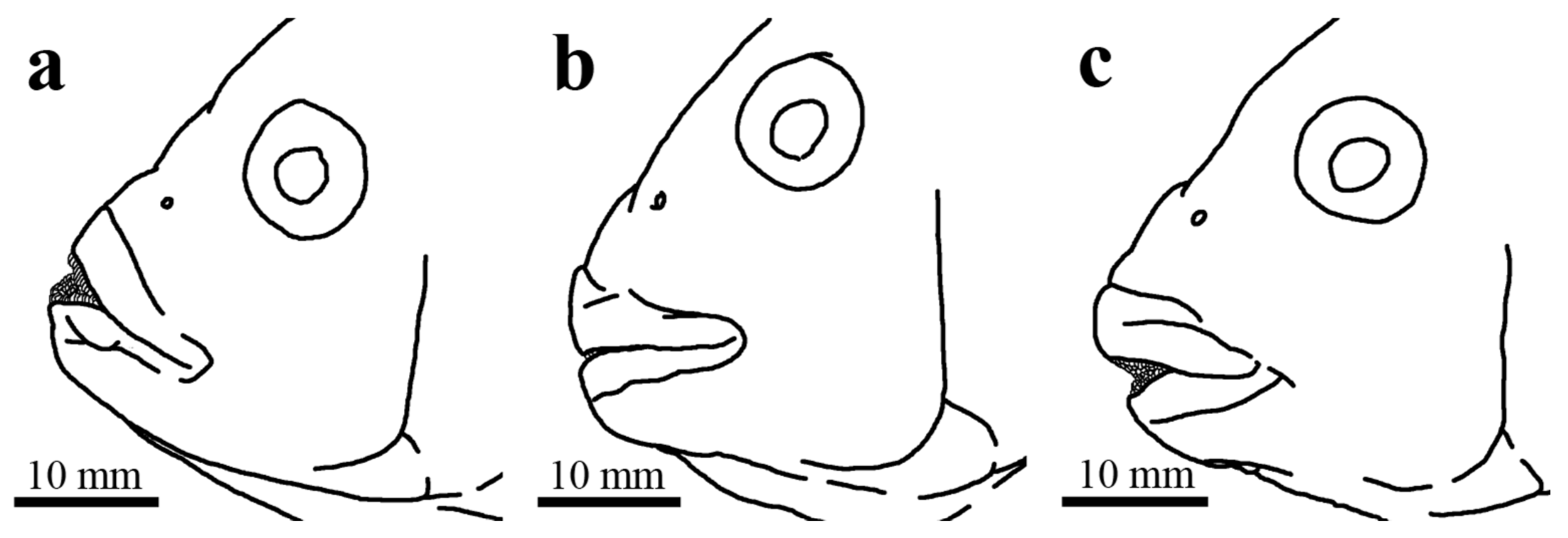

Fig. 5 
Table 1. Summary of specimens used for morphological analyses. See Table S1 for details of the sampling.

\begin{tabular}{|c|c|c|c|}
\hline & $\begin{array}{l}\text { No. and SL } \\
\text { (mm) of } \\
\text { females }\end{array}$ & $\begin{array}{l}\text { No. and SL } \\
(\mathrm{mm}) \text { of } \\
\text { males }\end{array}$ & Sampling localities \\
\hline Undescribed fish & $\begin{array}{l}N=8 \\
85.0-137.6\end{array}$ & $\begin{array}{l}N=4 \\
89.1-104.4\end{array}$ & Kasenga \\
\hline P. famula & $\begin{array}{l}N=8 \\
84.7-108.2\end{array}$ & $\begin{array}{l}N=12 \\
97.6-133.0\end{array}$ & $\begin{array}{l}\text { Pemba, Cape Muzimu, Kabimba, } \\
\text { Kasenga }\end{array}$ \\
\hline P. fasciolatus & $\begin{array}{l}N=11 \\
77.6-113.1\end{array}$ & $\begin{array}{l}N=10 \\
82.2-128.6\end{array}$ & $\begin{array}{l}\text { Pemba, Cape Muzimu, Kalemie, } \\
\text { Kapamba (= Kapampa?), baie de } \\
\text { Kilewa (= Kileba?), Kasenga }\end{array}$ \\
\hline P. macrognathus & $\begin{array}{l}N=10 \\
87.1-132.2\end{array}$ & $\begin{array}{l}N=11 \\
93.2-178.7\end{array}$ & Luhanga, Pemba, Sumbu, Kasenga \\
\hline P. orthognathus & $\begin{array}{l}N=11 \\
88.4-129.9\end{array}$ & $\begin{array}{l}N=15 \\
84.2-150.5\end{array}$ & $\begin{array}{l}\text { Pemba, Cape Muzimu, near Kalemie, } \\
\text { Cape Mpibmwe, Karema, Mkangasi, } \\
\text { near Bulu Point, Kiti Point, Kigoma, } \\
\text { near Nyanza, Gitaza }\end{array}$ \\
\hline P. polyodon & $\begin{array}{l}N=8 \\
101.6-149.6\end{array}$ & $\begin{array}{l}N=12 \\
77.3-179.8\end{array}$ & $\begin{array}{l}\text { Pemba, Cape Muzimu, Kalemie, } \\
\text { Mpulungu, Kasenga, Masaka Point, } \\
\text { Kigoma, near Nyanza }\end{array}$ \\
\hline
\end{tabular}




$\begin{array}{llll}\text { P. trewavasae } & N=10 & N=12 & \text { Pemba, Ubwari Peninsula, Cape } \\ & 77.3-145.3 & 77.1-153.3 & \text { Muzimu, Moliro, Chipimbi, Kasenga, }\end{array}$

Kigoma 
Table 2 Summary of characters that differ between the undescribed fish and the six known Petrochromis species with no or little overlaps

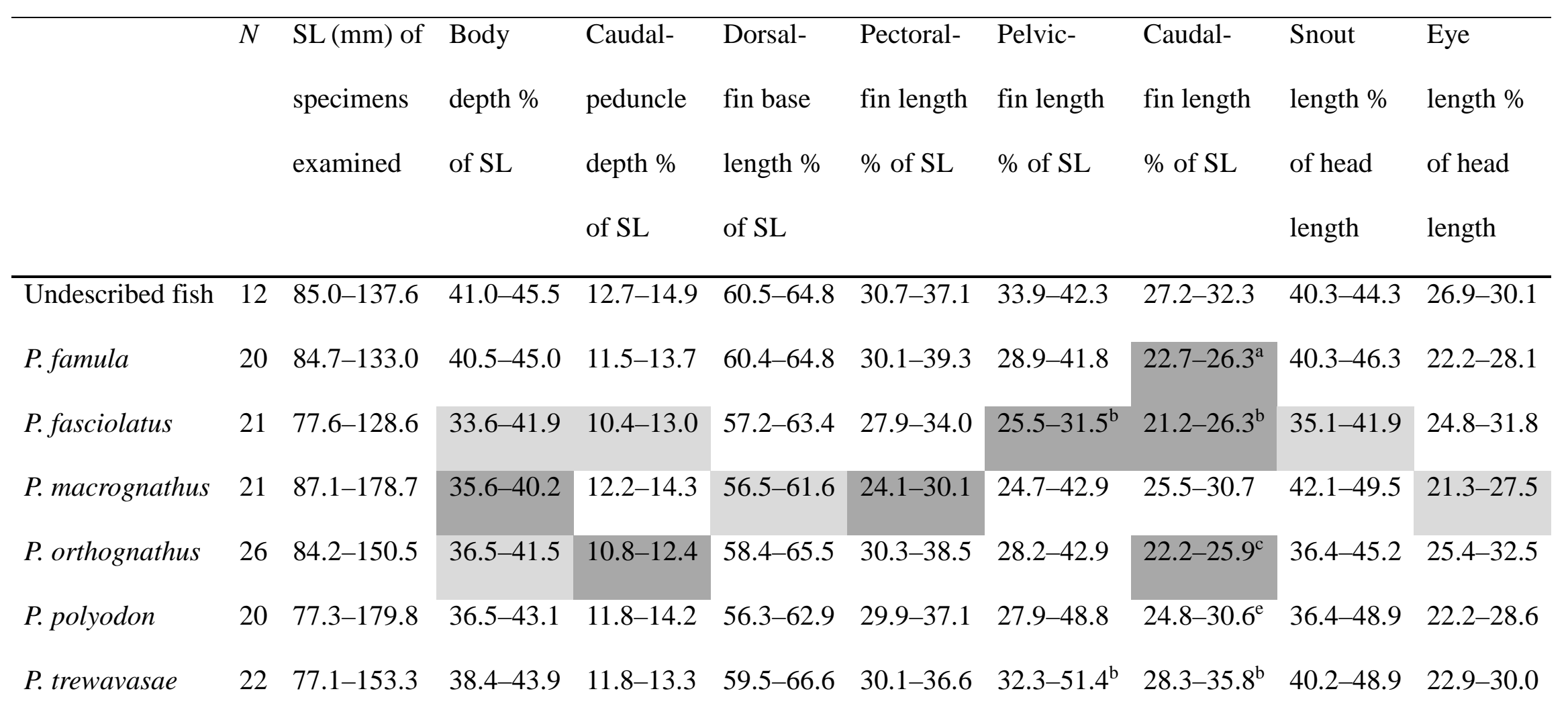

Shading indicates characters in which the values of all individuals (heavy shading) or $>90 \%$ individuals (light shading) are excluded from the ranges of the undescribed fish. ${ }^{\mathrm{a}} N=19 ;{ }^{\mathrm{b}} N=20 ;{ }^{\mathrm{c}} N=24 ;{ }^{\mathrm{d}} N=25 ;{ }^{\mathrm{e}} N=18$. 
Table 2 Continued (this is the right part of Table 2)

\begin{tabular}{llll}
\hline $\begin{array}{l}\text { Interorbital } \\
\text { width } \%\end{array}$ & $\begin{array}{l}\text { Upper-jaw } \\
\text { of head }\end{array}$ & Soft & Scales in \\
\% of head & dorsal & line \\
length & length & fin & \\
\hline $37.0-40.4$ & $0.6-4.6$ & $9-10$ & $34-35$ \\
\hline $33.3-38.2$ & $0.9-3.3$ & $8-10$ & $31-33$ \\
$32.3-40.1$ & -6.6 to -1.0 & $8-11$ & $33-34$ \\
\hline $28.8-33.9$ & $6.4-15.4$ & $11-12$ & $35-37$ \\
\hline $29.9-36.7$ & $0.6-4.0^{d}$ & $8-10$ & $31-33$ \\
\hline $31.2-40.5$ & $4.8-11.9$ & $9-11$ & $34-36$ \\
\hline $33.7-40.9$ & $5.2-9.3$ & $8-10$ & $34-35$ \\
\hline
\end{tabular}


Table 3 Results of 1) MANCOVA on $14 \log _{10}$-transformed morphometric characters, 2) ANCOVA on the upper jaw protrusion, and 3) MANOVA on eight meristic characters to test morphological differences between the undescribed fish and each of the six known Petrochromis species

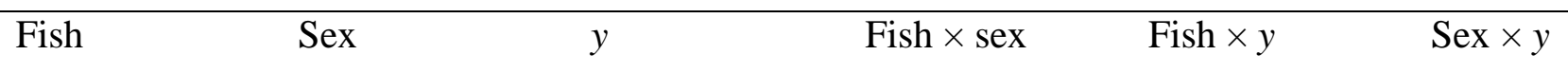

vs. P. famula

1) 14 morphometrics, $\quad y: \quad F_{(14,11)}=11.6^{* *} \quad F_{(14,11)}=1.80^{\mathrm{NS}} \quad F_{(14,11)}=95.8^{* *} \quad F_{(14,11)}=0.70^{\mathrm{NS}} \quad F_{(14,11)}=1.76^{\mathrm{NS}} \quad F_{(14,11)}=2.70^{\mathrm{NS}}$ $\log _{10}(\mathrm{SL})$

2) Upper-jaw protrusion, y: SL $\quad F_{(1,25)}=2.26^{\mathrm{NS}} \quad F_{(1,25)}=0.47^{\mathrm{NS}} \quad F_{(1,25)}=0.14^{\mathrm{NS}} \quad F_{(1,25)}=0.94^{\mathrm{NS}} \quad F_{(1,25)}=2.03^{\mathrm{NS}} \quad F_{(1,25)}=0.15^{\mathrm{NS}}$

3) 8 meristics

$F_{(8,21)}=14.6^{* *} \quad F_{(8,21)}=1.51^{\mathrm{NS}}$

$F_{(8,21)}=0.67^{\mathrm{NS}}$

vs. P. fasciolatus

14 morphometrics, $\quad y: \quad F_{(14,11)}=52.1^{* *} \quad F_{(14,11)}=0.86^{\mathrm{NS}} \quad F_{(14,11)}=259^{* *} \quad F_{(14,11)}=1.51^{\mathrm{NS}} \quad F_{(14,11)}=1.39^{\mathrm{NS}} \quad F_{(14,11)}=2.30^{\mathrm{NS}}$ $\log _{10}(\mathrm{SL})$

2) Upper-jaw protrusion, $y$ : SL

$F_{(1,26)}=148^{* *} \quad F_{(1,26)}=0.33^{\mathrm{NS}}$

$F_{(1,26)}=7.18^{\mathrm{NS}}$

$F_{(1,26)}=0.27^{\mathrm{NS}}$

$F_{(1,26)}=0.10^{\mathrm{NS}}$

$F_{(1,26)}=0.22^{\mathrm{NS}}$

3) 8 meristics

$F_{(8,21)}=3.45^{\mathrm{NS}} \quad F_{(8,21)}=0.37^{\mathrm{NS}}$

$F_{(8,21)}=1.05^{\mathrm{NS}}$

vs. P. macrognathus

1) 14 morphometrics, $\quad y: \quad F_{(14,12)}=26.0^{* *} \quad F_{(14,12)}=1.69^{\mathrm{NS}} \quad F_{(14,12)}=173^{* *} \quad F_{(14,12)}=0.40^{\mathrm{NS}} \quad F_{(14,12)}=0.88^{\mathrm{NS}} \quad F_{(14,12)}=1.20^{\mathrm{NS}}$ 
$\log _{10}(\mathrm{SL})$
2) Upper-jaw protrusion, $y:$ SL
$F_{(1,26)}=58.0^{* *} \quad F_{(1,26)}=3.97^{\mathrm{NS}}$
$F_{(1,26)}=2.49^{\mathrm{NS}}$
$F_{(1,26)}<0.01^{\mathrm{NS}}$
$F_{(1,26)}=1.24^{\mathrm{NS}}$
$F_{(1,26)}=1.89^{\mathrm{NS}}$

3) 8 meristics

$F_{(8,22)}=14.7^{* *} \quad F_{(8,22)}=0.56^{\mathrm{NS}}$

$F_{(8,22)}=0.31^{\mathrm{NS}}$

vs. P. orthognathus

1) 14 morphometrics, $y: F_{(14,16)}=19.9^{* *} \quad F_{(14,16)}=2.92^{\mathrm{NS}}$

$F_{(14,16)}=355^{* *} \quad F_{(14,16)}=1.11^{\mathrm{NS}} \quad F_{(14,16)}=1.10^{\mathrm{NS}} \quad F_{(14,16)}=1.53^{\mathrm{NS}}$ $\log _{10}(\mathrm{SL})$

2) Upper-jaw protrusion, $y:$ SL

$F_{(1,30)}=3.03^{\mathrm{NS}} \quad F_{(1,30)}=2.12^{\mathrm{NS}}$

$F_{(1,30)}=3.53^{\mathrm{NS}}$

$F_{(1,30)}=0.07^{\mathrm{NS}}$

$F_{(1,30)}=0.41^{\mathrm{NS}}$

$F_{(1,30)}=0.06^{\mathrm{NS}}$

3) 8 meristics

$F_{(8,27)}=37.1^{* *} \quad F_{(8,27)}=0.92^{\mathrm{NS}}$

$F_{(8,27)}=0.88^{\mathrm{NS}}$

vs. P. polyodon

1) 14
$\log _{10}(\mathrm{SL})$

2) Upper-jaw protrusion, $y:$ SL

$F_{(1,25)}=34.0^{* *} \quad F_{(1,25)}=2.54^{\mathrm{NS}}$

$F_{(1,25)}=0.01^{\mathrm{NS}}$

$F_{(1,25)}=0.02^{\mathrm{NS}}$

$F_{(1,25)}=0.47^{\mathrm{NS}}$

$F_{(1,25)}=1.00^{\mathrm{NS}}$

3) 8 meristics

$F_{(8,21)}=7.14^{* *} \quad F_{(8,21)}=0.31^{\mathrm{NS}}$

$F_{(8,21)}=0.81^{\mathrm{NS}}$

vs. P. trewavasae

14 morphometrics, $\quad y: \quad F_{(14,12)}=12.2^{* *} \quad F_{(14,12)}=1.08^{\mathrm{NS}} \quad F_{(14,12)}=127^{* *} \quad F_{(14,12)}=1.01^{\mathrm{NS}} \quad F_{(14,12)}=2.26^{\mathrm{NS}} \quad F_{(14,12)}=1.07^{\mathrm{NS}}$ $\log _{10}(\mathrm{SL})$ 
2) Upper-jaw protrusion, $y$ : SL $\quad F_{(1,27)}=82.8^{* *} \quad F_{(1,27)}=0.74^{\mathrm{NS}} \quad F_{(1,27)}=0.84^{\mathrm{NS}} \quad F_{(1,27)}=0.10^{\mathrm{NS}} \quad F_{(1,27)}=8.77^{\mathrm{NS}} \quad F_{(1,27)}<0.01^{\mathrm{NS}}$
3) 8 meristics
$F_{(8,23)}=7.40^{* *} \quad F_{(8,23)}=1.53^{\mathrm{NS}}$
$F_{(8,23)}=0.86^{\mathrm{NS}}$

${ }^{* *} \alpha<0.01(P<0.000556),{ }^{*} \alpha<0.05(P<0.00267),{ }^{\text {NS }} \alpha \geq 0.05(P \geq 0.00267)$ after a Bonferroni correction. 
Table 4 Morphometric and meristic characters of Petrochromis horii n. sp.

\begin{tabular}{lll}
\hline & Holotype & Paratypes \\
& Female & Seven females and four males \\
\hline SL (mm, female) & 137.6 & $85.0-130.3$ \\
SL (mm, male) & - & $89.1-104.4$ \\
Percentage of SL & & \\
Body depth & 43.2 & $41.0-45.5(43.4 \pm 1.4)$ \\
Head length & 34.4 & $31.6-33.7(32.5 \pm 0.8)$ \\
Caudal-peduncle length & 14.8 & $14.4-15.7(15.1 \pm 0.5)$ \\
Caudal-peduncle depth & 13.2 & $12.7-14.9(13.5 \pm 0.6)$ \\
Dorsal-fin base length & 60.5 & $61.7-64.8(63.1 \pm 0.9)$ \\
Anal-fin base length & 16.6 & $17.5-19.9(18.5 \pm 0.7)$ \\
Pectoral-fin length & 33.6 & $30.7-37.1(34.2 \pm 1.9)$ \\
Pelvic-fin length & 33.9 & $34.5-42.3(38.9 \pm 2.4)$ \\
Caudal-fin length & 29.7 & $27.2-32.3(29.8 \pm 1.4)$ \\
Percentage of head length & & \\
Head width & 38.2 & $37.0-40.4(38.5 \pm 1.0)$ \\
Snout length & 52.5 & $54.4-60.9(57.5 \pm 2.1)$ \\
Eye length & 44.3 & $40.3-43.3(41.5 \pm 0.9)$ \\
Interorbital width & 27.6 & $26.9-30.1(28.6 \pm 1.0)$ \\
Lower-jaw length & & $25.9-33.2(28.6 \pm 2.1)$ \\
\hline & & \\
\hline
\end{tabular}


Upper-jaw protrusion

0.6

$1.0-4.6(3.2 \pm 1.1)$

Meristic characters

Dorsal fin

$$
\text { XIX,9 XVIII,10 (5), XIX,9 (4), XIX,10 (2) }
$$

Anal fin

III,7

III,7 (2), III,8 (9)

Pectoral fin

16

15 (2), 16 (9)

Scales in longitudinal line

34

34 (8), 35 (3)

Scales on upper lateral line

24

23 (2), 24 (6), 25 (2), 26 (1)

Scales on lower lateral line

14

10 (1), 13 (2), 14 (6), 15 (1), 16 (1)

Scale rows between lateral lines

2 (11)

Gill rakers

11

11 (4), 12 (6), 13 (1)

Morphometric characters of paratypes are indicated as follows: minimum value-maximum value (mean \pm standard deviation). Meristic characters of paratypes are indicated as follows: observed value (number of paratypes). 


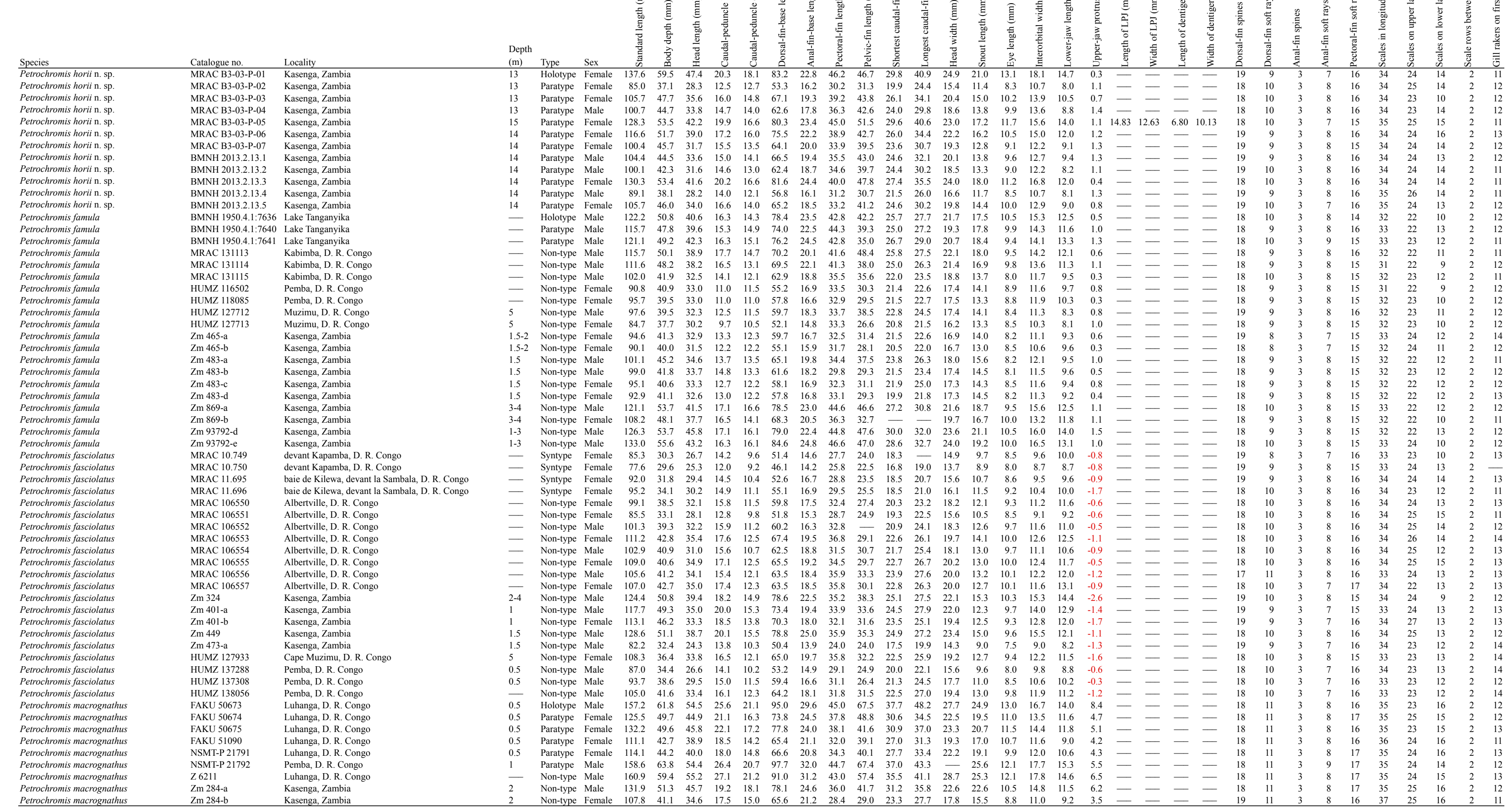




\begin{tabular}{|c|c|c|c|c|c|c|c|c|c|c|c|c|c|c|c|c|c|c|c|c|c|c|c|c|c|c|c|c|c|c|c|c|c|c|c|}
\hline Species & Catalogue no & & $\begin{array}{l}\text { Depth } \\
(\mathrm{m})\end{array}$ & Type & & 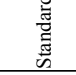 & 嵪 & 总 & 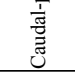 & 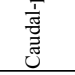 & 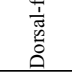 & 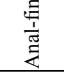 & 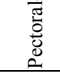 & $\frac{j}{2}$ & 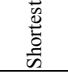 & $\underline{\underline{5}}$ & 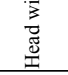 & 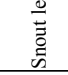 & $\begin{array}{l}\frac{5}{0} \\
\text { 畜 }\end{array}$ & 焉 & 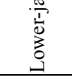 & 恴 & 紫 & $\frac{\bar{z}}{3}$ & 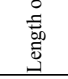 & 長 & 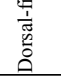 & 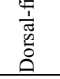 & $\begin{array}{l}\frac{5}{\frac{5}{9}} \\
\end{array}$ & 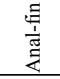 & 童 & 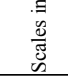 & 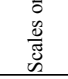 & 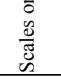 & 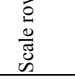 \\
\hline$\frac{P \text { Petrochromis macrognathus }}{}$ & Zm 284-c & Kasenga, Zambia & 2 & Non-type & Female & & & 30.2 & & & 50.3 & & 21.2 & & & $\frac{23.0}{23.0}$ & & 12.7 & & 8.7 & 6.5 & 4.0 & & 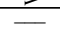 & 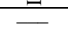 & & 18 & 12 & 3 & 8 & 17 & 36 & 26 & 15 & \\
\hline $\begin{array}{l}\text { Petrochromis macrognathus } \\
\text { Petrochomis }\end{array}$ & $\mathrm{Zm} 02170$ & Kasenga, Zambia & - & Non-type & Male & 95.1 & 34.0 & 32.7 & 14.0 & 12.5 & 56.1 & 18.3 & 22.9 & 25.8 & 21.7 & 25.3 & 16.0 & 14.2 & 8.0 & 100 & 7.4 & 4.0 & & 工 & - & 一 & 10 & 11 & 3 & 9 & 17 & 36 & 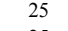 & 15 & \\
\hline trochromis macrognathus & $\begin{array}{l}\mathrm{Zm} 02573 \\
\mathrm{Zm} 02574\end{array}$ & $\begin{array}{l}\text { Kasenga, Zambia } \\
\text { Kasenga Zambia }\end{array}$ & 二 & $\begin{array}{l}\text { Non-type } \\
\text { Non-type }\end{array}$ & $\begin{array}{l}\text { Male } \\
\text { Male }\end{array}$ & $\begin{aligned} 118.9 \\
967\end{aligned}$ & $\begin{array}{l}45.1 \\
35.1\end{array}$ & $\begin{array}{l}38.0 \\
32.7\end{array}$ & $\begin{array}{l}17.5 \\
114\end{array}$ & $\begin{array}{l}16.7 \\
134\end{array}$ & $\begin{array}{l}70.9 \\
576\end{array}$ & 22.8 & $\begin{array}{l}30.5 \\
23.8\end{array}$ & $\begin{array}{l}35.7 \\
272\end{array}$ & $\begin{array}{l}27.4 \\
22.9\end{array}$ & $\begin{array}{l}32.7 \\
25.5\end{array}$ & 22.4 & $\begin{array}{l}16.2 \\
15.1\end{array}$ & $\begin{array}{l}9.5 \\
78\end{array}$ & & $\begin{array}{l}10.7 \\
7.6\end{array}$ & $\begin{array}{l}3.7 \\
3.9\end{array}$ & & & & & $\begin{array}{l}18 \\
18\end{array}$ & $\begin{array}{l}11 \\
12\end{array}$ & & & 17 & $\begin{array}{l}35 \\
35 \\
35\end{array}$ & 25 & 14 & \\
\hline $\begin{array}{l}\text { Petrocroromis macroganathus } \\
\text { Petrochromis macrognathus }\end{array}$ & $\begin{array}{l}\mathrm{Lm} 02534 \\
\mathrm{Zm} 02578\end{array}$ & $\begin{array}{l}\text { Kasenga, Zambia } \\
\text { Kasenga, Zambia }\end{array}$ & 二 & $\begin{array}{l}\text { Non-ype } \\
\text { Non-type }\end{array}$ & $\begin{array}{l}\text { Male } \\
\text { Female }\end{array}$ & $\begin{array}{r}96.7 \\
110.9\end{array}$ & $\begin{array}{l}33.1 \\
40.5\end{array}$ & $\begin{array}{l}32.1 \\
37.1\end{array}$ & $\begin{array}{l}14.1 \\
17.1\end{array}$ & $\begin{array}{l}13.4 \\
14.7\end{array}$ & $\begin{array}{l}5.6 \\
65.7\end{array}$ & 23.1 & $\begin{array}{l}23.8 \\
28.2\end{array}$ & $\begin{array}{l}27.2 \\
27.4\end{array}$ & 225.7 & $\begin{array}{l}29.3 \\
29.6\end{array}$ & $\begin{array}{l}1,1.2 \\
19.2\end{array}$ & $\begin{array}{l}15.1 \\
16.7\end{array}$ & $\begin{array}{l}7.8 \\
8.8\end{array}$ & 10.9 & $\begin{array}{l}7.6 \\
9.9\end{array}$ & 3.5 & & & & & $\begin{array}{l}18 \\
18\end{array}$ & 11 & & $88+2-2$ & $\begin{array}{l}16 \\
16\end{array}$ & 35 & $\begin{array}{l}24 \\
26\end{array}$ & $\begin{array}{l}14 \\
14\end{array}$ & \\
\hline$x^{2}+2$ & & & & Non-type & Female & 120.1 & 43.6 & 39.0 & & & & 24.0 & 31.7 & & & 31.3 & & 117 & & & & 2.5 & & & & & 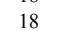 & 11 & & & 16 & & & & \\
\hline nnathus & $\mathrm{Zm} 03532$ & Kasenga, Zambia & - & Non-type & Male & 110.2 & 39.2 & 36.3 & & & 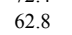 & 015 & 29.7 & 31.8 & 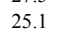 & & . & 150 & & 110 & 8.6 & 4.7 & & & & & & & & & 16 & & & & \\
\hline Petrochromis macrognathus & $\mathrm{Zm} 0127$ & Kasenga, Zambia & - & Non-type & Male & & & & & 13.3 & 54.8 & & & & & & & 13.3 & & & & 2.9 & & & & & & & & & 17 & & & & \\
\hline Petrochromis macrognathus & $\mathrm{Zm} 0323$ & Kasenga, Zambia & - & Non-type & Female & 117.5 & 47.0 & 39.6 & 19.0 & 16.0 & 70.7 & 22.7 & 34.0 & 37.1 & 29.9 & 34.9 & 21.2 & 19.0 & 9.2 & 12.5 & 10.2 & 3.9 & & - & 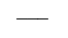 & - & 18 & 12 & 3 & F & 17 & 36 & 25 & 17 & \\
\hline ochromis macrognathus & HUMZ 122890 & Cape Kanchese, Sumbu, Zambia & - & Non-type & Female & 127.8 & 45.8 & 42.8 & 18.7 & 16.5 & 73.4 & 23.8 & 36.0 & 44.0 & 31.5 & 35.7 & 21.1 & 20.5 & 11.1 & 13.4 & 11.6 & 3.5 & & & & - & 10 & 11 & 3 & 9 & 16 & 36 & 25 & 15 & \\
\hline $\begin{array}{l}\text { rochromis macrognathus } \\
\text { rochromis macrognathus }\end{array}$ & $\begin{array}{l}\text { HUMZ } 122901 \\
\text { HUMZ } 128694\end{array}$ & $\begin{array}{l}\text { Cape Kanchese, Sumbu, Zambia } \\
\text { Kahoma (?) D R R Congo }\end{array}$ & & $\begin{array}{l}\text { Non-type } \\
\text { Non-type }\end{array}$ & $\begin{array}{l}\text { Male } \\
\text { Male }\end{array}$ & $\begin{array}{l}1787.7 \\
1477\end{array}$ & $\begin{array}{l}65.7 \\
52.9\end{array}$ & $\begin{array}{l}61.9 \\
49.5\end{array}$ & $\begin{array}{l}26.9 \\
26.6\end{array}$ & $\begin{array}{l}22.5 \mathrm{~S}^{2} \mathrm{l} \\
18.0\end{array}$ & $\begin{array}{r}103.5 \\
83.4\end{array}$ & $\begin{array}{ll}35.7 \\
25.5\end{array}$ & $\begin{aligned} 50.6 \\
39.2\end{aligned}$ & $\begin{array}{l}63.1 \\
49.7\end{array}$ & $\begin{array}{l}41.1 \\
313 \\
313\end{array}$ & $\begin{array}{l}49.8 \\
39.5 \\
-\end{array}$ & $\begin{array}{l}30.2 \\
251\end{array}$ & $\begin{array}{l}30.0 \\
220\end{array}$ & $\begin{array}{l}13.2 \\
11.5\end{array}$ & $\begin{array}{l}18.0 \\
16.2\end{array}$ & $\begin{array}{l}14.5 \\
12.2\end{array}$ & 6.11 & & & & - & $\begin{array}{l}18 \\
18\end{array}$ & ${ }_{11}^{11}$ & & $\begin{array}{r}10 \\
8\end{array}$ & $\begin{array}{l}17 \\
16\end{array}$ & 36 & $\begin{array}{l}24 \\
25\end{array}$ & $\begin{array}{l}17 \\
17\end{array}$ & \\
\hline $\begin{array}{l}\text { Petrochromis macrogianthus } \\
\text { Petrochromis orthognathus }\end{array}$ & $\begin{array}{l}\text { HUML } \\
\text { MRAC 125.150 }\end{array}$ & $\begin{array}{l}\text { Kanoma (3), D. . C.Congo } \\
\text { Bemba, km } 155 \text { route Uvi }\end{array}$ & $\overline{2-5}$ & $\begin{array}{l}\begin{array}{l}\text { Non-ylype } \\
\text { Holotype }\end{array} \\
\text { S }\end{array}$ & $\begin{array}{l}\text { Male } \\
\text { Male }\end{array}$ & $\begin{array}{l}14.1 \\
131.7\end{array}$ & $\begin{array}{l}22.9 \\
52.2\end{array}$ & $\begin{array}{l}49.3 .4 \\
41.4\end{array}$ & $\begin{array}{l}20.6 \\
19.7\end{array}$ & $\begin{array}{l}18.0 \\
14.8\end{array}$ & $\begin{array}{l}8.4 \\
82.5\end{array}-10$ & 23.0 & $\begin{array}{l}39.2 \\
44.7\end{array}$ & $\begin{array}{l}45.1 \\
45.6\end{array}$ & 27.3 & $\begin{array}{l}39.3 \\
32.1\end{array}$ & $\begin{array}{l}23.1 \\
23.9\end{array}$ & $\begin{array}{l}22.09 \\
18.7\end{array}$ & $\begin{array}{l}11.9 \\
10.5\end{array}$ & $\begin{array}{l}10.2 \\
14.1\end{array}$ & $\begin{array}{l}12.2 \\
11.4\end{array}$ & $\begin{array}{l}3.4 \\
0.7\end{array}$ & & & & & 19 & 9 & & 8 & $\begin{array}{l}16 \\
16\end{array}$ & 32 & ${ }_{23}^{23}$ & & \\
\hline rochromis ot & RAC 125180 & Entre Albertville et le ca & & Non-type & & 150.5 & 54.9 & & & $1 . \infty$ & 90.2 & 25.6 & & & 31.5 & 35.1 & 25.5 & 20.0 & 13.1 & 15.8 & & . & & & & & & & & & & 31 & & & \\
\hline hromis orthognathus & JMZ 116553 & Pemba, D. R. Congo & - & Non-type & Male & 99.3 & 40.6 & 32.6 & 13.5 & 12.0 & 63.3 & 16.8 & 38.2 & 36.2 & & 25.6 & 18.6 & 13.1 & & 11.1 & 9.5 & $0=$ & & & & & & & & & & & 23 & & \\
\hline rochromis o & JMZ 116674 & Pemba, D. R. Congo & - & Non-type & Female & 129.9 & 51.2 & 41.7 & 18.0 & 14.7 & 77.0 & 20.6 & 39.4 & 39.5 & 26.7 & 30.5 & 22.5 & 18.0 & 11.9 & 15.3 & 12.8 & & & & & & & - & & & 14 & 33 & P & & \\
\hline rochromis orthognathus & HUMZ 118079 & Pemba, D. R. Congo & - & Non-type & Female & 92.7 & 37.7 & 29.2 & 13.6 & 10.7 & 59.4 & 15.0 & 32.7 & 29.9 & 21.0 & 23.0 & 16.5 & 11.9 & 8.2 & 9.8 & 8.4 & 0.4 & & - & & - & 19 & 10 & & 7 & 15 & 33 & 24 & 11 & \\
\hline Aromis orthognathus & HUMZ 118086 & Pemba, D. R. Congo & $\overline{10}$ & on-type & Female & 107.1 & & 34.5 & & 12.2 & 66.0 & 18.5 & 36.9 & 34.4 & 22.5 & 25.1 & 18.6 & 14.8 & 9.6 & 11.6 & 9.8 & 0.7 & & & - & - & 19 & 9 & & 7 & 15 & 33 & 23 & 11 & \\
\hline $\begin{array}{l}\text { hiromis orthognathus } \\
\text { hromis orthonothas }\end{array}$ & $\begin{array}{l}\text { HUMZ } 127387 \\
\text { HUMZ } 127388\end{array}$ & $\begin{array}{l}\text { Gitaza, Burundi } \\
\text { Gitaza Burudi }\end{array}$ & ${ }_{12}^{12}$ & Non-type & Female & $\begin{array}{l}108.5 \\
123.9\end{array}$ & $\begin{array}{l}44.2 \\
49.8\end{array}$ & $\begin{array}{l}35.2 \\
394\end{array}$ & $\begin{array}{l}15.5 \\
1193\end{array}$ & $\begin{array}{l}12.3 \\
146\end{array}$ & $\begin{array}{l}64.9 \\
779\end{array}$ & 17.2 & 35.9 & 32.9 & 23.8 & 25.9 & ${ }_{231}^{19.3}$ & 15.7 & 10.0 & 12.5 & $\begin{array}{l}10.0 \\
118\end{array}$ & 0.4 & & & - & - & & 8 & 3 & 7 & 15 & 32 & 24 & 10 & \\
\hline $\begin{array}{l}\text { Trochromis orthognanthus } \\
\text { rochromis orthogathus }\end{array}$ & JMZ 127390 & $\begin{array}{l}\text { Gitaza, Burundi } \\
\text { Gitaza, Burundi }\end{array}$ & $\begin{array}{l}12 \\
12\end{array}$ & $\begin{array}{l}\text { Non-ype } \\
\text { Non-type }\end{array}$ & $\begin{array}{l}\text { Male } \\
\text { Female }\end{array}$ & $\begin{array}{l}123.9 \\
101.1\end{array}$ & $\begin{array}{l}49.8 \\
42.0\end{array}$ & $\begin{array}{l}39.4 \\
32.6\end{array}$ & $\begin{array}{l}19.3 \\
14.7\end{array}$ & $\begin{array}{l}14.6 \\
12.5\end{array}$ & 60.8 & $\begin{array}{l}21.4 \\
16.9\end{array}$ & $\begin{array}{l}42.3 \\
32.6\end{array}$ & $\begin{array}{l}46.6 \\
30.0\end{array}$ & $\begin{array}{l}26.0 \\
22.2\end{array}$ & 23.4 & $\begin{array}{l}23.1 \\
17.5\end{array}$ & $\begin{array}{l}10.3 \\
13.1\end{array}$ & $\begin{array}{r}11.0 \\
9.4\end{array}$ & $\begin{array}{l}14.3 \\
11.1\end{array}$ & $\begin{array}{r}11.8 \\
8.7\end{array}$ & 0.7 & & & & 二 & 18 & & & & 14 & 32 & 22 & & \\
\hline ggnathus & 23 & Moguruka near Nyanza, Burundi & & Non-type & Female & 99.8 & $\begin{array}{l}38.0 \\
38.0\end{array}$ & $\begin{array}{r}32.9 \\
32.9\end{array}$ & & 11.4 & 60.5 & 17.6 & & & 21.6 & 23.5 & & $\begin{array}{l}13.1 \\
13.0\end{array}$ & 10.0 & 10.6 & 10.2 & .5 & & & & & & & & & & & & & \\
\hline orthognathus & JMZ 127426 & Moguruka near Nyanza, Burundi & - & Non-type & Male & 109.9 & 41.5 & 33.6 & 15.0 & 12.9 & 69.2 & 19.8 & 38.1 & 35.1 & 27.1 & & 19.2 & & 10.1 & 11.5 & & & & & & & & & & & & & & & \\
\hline rochromis orthognathus & MZ 127427 & Moguruka near Nyanza, Burundi & - & Non-type & Male & 130.4 & 49.2 & 39.8 & 19.3 & 15.0 & 81.8 & 24.1 & 42.6 & 39.5 & 28.6 & 31.4 & & 16.7 & 11.6 & 14.3 & 12.1 & 4 & & & & & & & & & & & 23 & 1 & \\
\hline rochromis orthognathus & HUMZ 127510 & Moguruka near Nyanza, B & - & Non-type & Male & 134.9 & 50.5 & 41.4 & & 15.3 & 83.3 & 22.6 & 44.7 & 57.9 & 29.0 & 32.4 & 23.0 & 17.2 & 12.2 & 14.5 & 11.8 & 1.0 & & & - & - & 18 & 9 & & & 16 & 32 & 23 & & \\
\hline gnathus & JMZ 127511 & guruka near Nyanza, 1 & & $\begin{array}{l}\text { Non-type } \\
\text { Non-type }\end{array}$ & Male & 97.2 & 36.9 & 30.2 & & 11.8 & 61.6 & 17.3 & 30.2 & 33.9 & 21.5 & 23.4 & 17.0 & 12.1 & 9.3 & 10.4 & 8.7 & 0.6 & & & & - & 19 & 9 & & & 15 & 32 & 24 & 0 & \\
\hline $\begin{array}{l}\text { sorthognathus } \\
\text { sorthogathus } \\
\text { ons }\end{array}$ & $\begin{array}{l}\text { HUMZ } 1277977 \\
\text { HUMZ 127699 }\end{array}$ & $\begin{array}{l}\text { mu, D. R. Congo } \\
\text { mu D. R Congo }\end{array}$ & $\begin{array}{r}4-5 \\
4-5\end{array}$ & $\begin{array}{l}\text { Non-type } \\
\text { Nonetyno }\end{array}$ & $\begin{array}{l}\text { Female } \\
\text { Female }\end{array}$ & 116.0 & $\begin{array}{l}43.0 \\
3.75\end{array}$ & 39.1 & 18.0 & $\begin{array}{l}12.9 \\
11.4\end{array}$ & $\begin{array}{l}67.8 \\
59.1\end{array}$ & 18.6 & $\begin{array}{r}40.5 \\
340\end{array}$ & 36.4 & 24.9 & & 19.7 & 14.8 & 11.5 & 2.0 & 9.8 & & & & & - & 18 & & & & 15 & 32 & 23 & 99 & \\
\hline $\begin{array}{l}\text { ologatritus } \\
\text { iognathus }\end{array}$ & UMZ 127714 & $\begin{array}{l}\mathrm{mu} \text { m, D. R. Congo } \\
\mathrm{mu} \text {, D. R. Congo }\end{array}$ & $\begin{array}{l}4-3 \\
4-5\end{array}$ & $\begin{array}{l}\text { Non-ype } \\
\text { Non-type }\end{array}$ & $\begin{array}{l}\text { Female } \\
\text { Male }\end{array}$ & $\begin{array}{r}92.6 \\
105.9\end{array}$ & $\begin{array}{l}15.3 .6 \\
43.6\end{array}$ & $\begin{array}{l}33.7 \\
33.7\end{array}$ & $\begin{array}{l}15.1 \\
14.6\end{array}$ & $\begin{array}{l}11.4 \\
12.9\end{array}$ & $\begin{array}{l}59.1 \\
68.6\end{array}$ & $\begin{array}{l}15.4 \\
17.4\end{array}$ & $\begin{array}{l}34.0 \\
38.8\end{array}$ & $\begin{array}{l}30.0 \\
42.6\end{array}$ & 24.3 & 27.4 & $\begin{array}{l}17.3 \\
19.0\end{array}$ & $\begin{array}{l}11.1 .9 \\
13.9\end{array}$ & $\begin{array}{l}9.6 \\
9.7\end{array}$ & $\begin{array}{l}10.3 \\
12.0\end{array}$ & $\begin{array}{l}9.4 \\
10.5\end{array}$ & & & & & 二 & & & & & 15 & $\begin{array}{l}32 \\
32\end{array}$ & 23 & & \\
\hline tus & & & $4-5$ & Non-type & Male & & & & & 12.9 & 81.2 & & & & & & & & & & & 15 & & & & & & & & & & & & & \\
\hline nathus & $\mathrm{Z} 127720$ & ongo & $4-5$ & Non-type & Male & 134.8 & & & & & & & & & & & & & & 14.6 & 10.7 & & & & & & & & & & & & & & \\
\hline nas & & Catonga Marchet, Kigol & & Non-type & Female & 106.8 & 41.5 & 33.4 & 15.5 & 13.2 & 66.1 & 19.9 & 35.8 & 30.1 & 22.9 & 25.0 & 19.2 & 13.2 & 9.9 & 11.7 & 10.4 & 1.0 & - & - & & - & 19 & & & & 16 & 32 & & & \\
\hline is "ikola" & MRAC 92081.0592 & Mpimbwe Hills, southern part of Sha & - & Non-type & Male & 127.1 & 51.7 & 41.4 & & 13.7 & 81.7 & 22.6 & 42.5 & 45.0 & 26.6 & 29.2 & 22.1 & 17.6 & 12.0 & 14.8 & 12.0 & 1.5 & - & - & - & - & 15 & 9 & & 7 & 16 & 33 & 23 & 13 & \\
\hline 隹 & & iin $>$ & - & Non-type & Female & & 36.4 & 30.8 & & 10.3 & 57.0 & 15.6 & 33.2 & 31.0 & & & 15.4 & 11.6 & 9.5 & 9.7 & 8.6 & 1.2 & - & - & 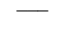 & - & 19 & & & 7 & 15 & 32 & 4 & 12 & \\
\hline si & & & 二 & $\begin{array}{l}\text { Non-type } \\
\text { Nonetyno }\end{array}$ & $\begin{array}{l}\text { Famale } \\
\text { Male }\end{array}$ & $\begin{array}{l}88.4 \\
95.9\end{array}$ & $\begin{array}{l}35.5 \\
37.1\end{array}$ & $\begin{array}{l}29.3 \\
30.0\end{array}$ & $\begin{array}{l}13.1 \\
13.6\end{array}$ & 11.4 & 55.6 & $\begin{array}{l}16.9 \\
164\end{array}$ & $\begin{array}{l}29.9 \\
32.1\end{array}$ & & & 220 & $\begin{array}{l}15.1 \\
16.5\end{array}$ & & 93 & 92 & $\begin{array}{l}8.2 \\
8.5\end{array}$ & & & & - & & & & & & 15 & 32 & & & \\
\hline rochror & $\begin{array}{l}\text { MRAC9 } \\
\text { MRAC } 9\end{array}$ & $\begin{array}{l}\text { Just sout } \\
? \pm 3 \mathrm{~km} ! \\
1\end{array}$ & 二 & $\begin{array}{l}\text { Non-ype } \\
\text { Non-type }\end{array}$ & $\begin{array}{l}\text { Male } \\
\text { Male }\end{array}$ & $\begin{array}{r}95.9 \\
108.0\end{array}$ & $\begin{array}{l}51.1 \\
43.3\end{array}$ & $\begin{array}{l}30.0 \\
35.7\end{array}$ & $\begin{array}{l}15.6 \\
14.3\end{array}$ & $\begin{array}{l}11.4 \\
12.7\end{array}$ & $\begin{array}{l}60.3 . \\
66.4\end{array}$ & $\begin{array}{l}10.4 \\
17.8\end{array}$ & $\begin{array}{l}22.1 \\
38.0\end{array}$ & $\begin{array}{l}13.2 \\
39.0\end{array}$ & $\begin{array}{l}19.3 \\
23.0\end{array}$ & $\begin{array}{l}22.0 \\
24.0\end{array}$ & $\begin{array}{l}16.9 \\
19.1\end{array}$ & $\begin{array}{l}12.00 \\
14.2\end{array}$ & $\begin{array}{r}9.3 \\
10.7\end{array}$ & $\begin{array}{l}9.2 \\
11.8\end{array}$ & $\begin{array}{l}8.9 \\
10.4\end{array}$ & 1.3 & & & & 二 & & & & & & $\begin{array}{l}33 \\
32\end{array}$ & $\begin{array}{l}23 \\
23\end{array}$ & & \\
\hline thus " & & & - & Non-type & Male & & 33.6 & & & & $\begin{array}{l}50.4 \\
53.6\end{array}$ & $\begin{array}{l}14.1 \\
14.1\end{array}$ & $\begin{array}{l}30.0 \\
30.2\end{array}$ & & 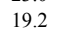 & $\begin{array}{l}24.0 \\
21.6\end{array}$ & $\begin{array}{l}19.1 \\
13.6\end{array}$ & $\begin{array}{l}14.2 \\
9.6\end{array}$ & 8.2 & & 7.2 & 0.9 & & & & & & & & & & & & & \\
\hline & & & - & Syntype & Male & 79.6 & 32.9 & 28.3 & & & & & & 28.5 & 20.2 & 22.8 & 15.0 & 10.3 & & & & & & & & & & & & & & & & & \\
\hline & & & - & Syntype & Female & 108.1 & 41.3 & 38.2 & 18.1 & 14.2 & 61.0 & 18.0 & 35.9 & & 26.0 & & & & 10.6 & 11.9 & 11.0 & & & & - & - & 19 & & & & & 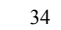 & & & \\
\hline lon & & R. Congo & - & Non-type & Female & 138.7 & 54.4 & 47.5 & 21.3 & 16.9 & 79.1 & 26.7 & 45.2 & 42.1 & 32.6 & 37.0 & 24.0 & 20.6 & 11.9 & 14.8 & 13.0 & 2.5 & & 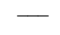 & 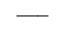 & - & 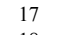 & 11 & & & 17 & 35 & & 14 & \\
\hline & & & - & ype & $\mathrm{Ma}$ & $\begin{array}{l}77.3 \\
\end{array}$ & 30.2 & & & & & & 24.2 & & & & 12.9 & 11.1 & 7.6 & 8.7 & 6 & 3.2 & - & - & - & - & 18 & & & & 5 & 34 & & & \\
\hline & & & 二 & -type & $\begin{array}{l}\text { Male } \\
\text { Male }\end{array}$ & 162.2 & $\begin{array}{l}62.6 \\
65.4\end{array}$ & $\begin{array}{l}52.1 \\
51.3\end{array}$ & $\begin{array}{l}25.9 \\
2.9\end{array}$ & $\begin{array}{l}19.4 \\
203\end{array}$ & $\begin{array}{l}92.2 \\
09.1\end{array}$ & $\begin{aligned} 27.2 \\
27\end{aligned}$ & $\begin{array}{l}49.7 \\
55.6\end{array}$ & 63.3 & & $\begin{array}{l}42.3 \\
460\end{array}$ & $\begin{array}{l}28.2 \\
28.2\end{array}$ & $\begin{array}{l}24.2 \\
240\end{array}$ & $\begin{array}{l}12.9 \\
132\end{array}$ & $\begin{array}{l}21.1 \\
200\end{array}$ & $\begin{array}{l}14.1 \\
15.1\end{array}$ & $\begin{array}{l}3.1 \\
3.1\end{array}$ & & 二 & - & - & 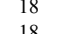 & & & & 16 & ${ }_{34}^{35}$ & & 14 & \\
\hline & & $\begin{array}{l}\text { surum } \\
\text { go }\end{array}$ & 5 & $\begin{array}{l}\text { Non-type } \\
\text { Non-type }\end{array}$ & $\begin{array}{l}\text { Male } \\
\text { Male }\end{array}$ & $\begin{array}{l}162.3 \\
109.3\end{array}$ & $\begin{array}{l}\text { 50.4.4 } \\
44.0\end{array}$ & $\begin{array}{l}11.3 . \\
36.4\end{array}$ & $\begin{array}{l}26 \\
18\end{array}$ & $\begin{array}{l}20.3 \\
13.7\end{array}$ & $\begin{array}{l}95.1 \\
66.0\end{array}$ & $\begin{array}{l}29.1 \\
19.4\end{array}$ & $\begin{array}{l}11.6 \\
37.0\end{array}$ & $\begin{array}{l}00.8 \\
45.3\end{array}$ & 26.4 & $\begin{array}{l}46.0 \\
32.1\end{array}$ & $\begin{array}{l}29.2 \\
19.7\end{array}$ & $\begin{array}{l}42.0 \\
15.8\end{array}$ & $\begin{array}{r}1.2 .2 \\
93\end{array}$ & .0 & $\begin{array}{r}15.4 \\
9.7\end{array}$ & & & Z & 二 & 二 & & & & & & 35 & & & \\
\hline & & & 5 & & Female & 109.3 & $\begin{array}{l}4+.00 \\
42.0\end{array}$ & $\begin{array}{l}00.4 \\
38.3\end{array}$ & & & 00.00 & $\begin{array}{l}29.4 \\
20.2\end{array}$ & 36.7 & 40.4 & & $\begin{array}{l}32.1 \\
32.5\end{array}$ & 19.6 & 16.7 & 10.4 & 0 & 3.1 & .7 & & 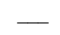 & & & & & & & & & & & \\
\hline & & & 5 & & Male & & & 44.7 & 19.0 & & & & & & & & 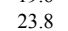 & 20.8 & 11.5 & & $12.2-2=2$ & & & & & & & & & & & & & & \\
\hline & & & 5 & & & 142.9 & 59.4 & 46.3 & 22.3 & & 85.9 & & & & 33.4 & 42.5 & & & 12.1 & 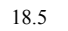 & 11 & & & & & & & & & & & & & & \\
\hline & & & 1 & & $\mathrm{M}$ & 158.1 & 64.4 & 51.3 & 24.6 & 19.0 & 95.3 & 27.3 & 54.4 & 77.2 & 37.1 & 47.5 & 28.0 & 24.5 & 13.0 & 18.9 & 14.6 & & & & - & - & 10 & $y$ & & & 16 & 34 & & 12 & \\
\hline & & & & e & M & & 38.9 & 32.0 & & 11.6 & & 17.8 & 32.9 & 37.3 & & 27.5 & 17.9 & 13 & 9.0 & 11.1 & & & & & & & & & & & 6 & & & & \\
\hline & & & & & & $\begin{array}{l}107.8 \\
1657\end{array}$ & $\begin{array}{l}44.8 \\
{ }_{714}\end{array}$ & $\begin{array}{l}36.8 \\
536.8\end{array}$ & $\begin{array}{l}16.3 \\
2.3\end{array}$ & & & 18.8 & $\begin{array}{l}40.0 \\
53.1\end{array}$ & $\begin{array}{l}39.0 \\
7.68\end{array}$ & & & $\begin{array}{l}21.1 \\
20.7\end{array}$ & $\begin{array}{l}16.6 \\
257\end{array}$ & $\begin{array}{r}9.6 \\
129\end{array}$ & 6 & & & & & & & 18 & & & & 16 & 35 & & 14 & \\
\hline & & $\begin{array}{l}\mathrm{K} \\
\mathrm{K}\end{array}$ & $\begin{array}{l}1-3 \\
1-3\end{array}$ & & $\begin{array}{l}\mathrm{Ma}_{2} \\
\mathrm{M}_{2}\end{array}$ & $\begin{array}{l}165.7 \\
179.8\end{array}$ & $\begin{array}{l}11.4 \\
72.0\end{array}$ & $\begin{array}{l}35.6 \\
59.9\end{array}$ & $\begin{array}{l}28.6 \\
28.5\end{array}$ & $\begin{array}{ll}22.11 & 1 \\
23.4 & 1\end{array}$ & $\begin{array}{l}100.5 \\
113.1\end{array}$ & $\begin{array}{l}\begin{array}{l}31.0 \\
33.4\end{array} \\
3\end{array}$ & $\begin{array}{l}53.1 \\
53.7\end{array}$ & $\begin{array}{l}10.8 \\
66.7\end{array}$ & $\begin{array}{l}36.4 \\
39.2\end{array}$ & $\begin{array}{l}45.9 \\
44.6\end{array}$ & & & $\begin{array}{l}12.9 \\
133\end{array}$ & & & & & & & & & & & & & & & & \\
\hline & & & & & & & $2: 0.0$ & & & & & $\begin{array}{l}25.4 .1 \\
25.1\end{array}$ & & & & & 25.8 & & 12.6 & & 6.0 & & & & & & & & & & & & & & \\
\hline & & & & & & $11:$ & & & 18 & & & & & & & & & & . & & & & & & & & & & & & & & & & \\
\hline & & & 1 & & & 103 & & & 16 & 13.3 & 1 & & & & & & & & 10.0 & & & & & & & & & & & & & & & & \\
\hline & & & $1-3$ & ype & Female & 101.6 & 42.7 & 34.3 & 16.6 & 14.0 & 61.5 & 18.2 & 33.2 & 36.2 & 23.7 & 27.9 & 17.8 & 14 & 9.3 & 11.7 & & & & & & & 10 & 3 & & & 16 & 35 & 26 & 5 & \\
\hline & & $\mathrm{p}$ & 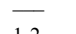 & Non-type & $\mathrm{Fe}$ & $\begin{array}{l}116.0 \\
077\end{array}$ & 42.3 & 37.2 & 18.9 & 14.1 & 67.9 & 20.7 & 37.3 & 39.4 & 25.7 & 30.5 & 19.7 & 16.2 & 10.1 & 12.8 & 10.4 & 2.3 & & & & & 18 & & & & 17 & 35 & 23 & & \\
\hline & & & $1-2$ & $\begin{array}{l}\text { Holotype } \\
\text { Non }\end{array}$ & & $\begin{array}{l}87.7 \\
\end{array}$ & $\begin{array}{l}36.4 \\
550\end{array}$ & $\begin{array}{l}30.4 \\
403\end{array}$ & $\begin{array}{l}11.5 \\
1.67\end{array}$ & 6 & $\begin{array}{l}55.8 \\
775\end{array}$ & $\begin{array}{l}17.3 \\
018\end{array}$ & $\begin{array}{l}26.4 \\
410\end{array}$ & & $\begin{array}{l}19.0 \\
270\end{array}$ & & $\begin{array}{l}15.8 \\
22.4\end{array}$ & $\begin{array}{l}13.6 \\
207\end{array}$ & $\begin{array}{l}7.8 \\
97\end{array}$ & $\begin{array}{ll}11.2 \\
173\end{array}$ & & $\begin{array}{l}2.44 \\
36\end{array}$ & & 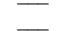 & 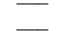 & 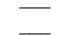 & & & & & 15 & 35 & 24 & & \\
\hline ewavasase & & bl, Lambla & 二 & $\begin{array}{l}\text { Non-ype } \\
\text { Non-type }\end{array}$ & $\begin{array}{l}\text { Male } \\
\text { Male }\end{array}$ & $\begin{array}{l}120.1 \\
120.0\end{array}$ & $\begin{array}{l}22.0 \\
49.1\end{array}$ & $\begin{array}{l}{ }_{42.3}^{2.3} \\
42.1\end{array}$ & 17.3 & .1 & 73.8 & $\begin{array}{l}\begin{array}{l}11.8 \\
20.2\end{array} \\
2\end{array}$ & $\begin{array}{l}\begin{array}{l}41.0 \\
37.5\end{array} \\
\end{array}$ & $\begin{array}{l}35.8 \\
42.1\end{array}$ & $\begin{array}{l}27.1 \\
26.4\end{array}$ & $\begin{array}{l}42.0 \\
43.0\end{array}$ & $\begin{array}{l}22.4 . \\
21.3\end{array}$ & & & & & 3.4 & & & 二 & 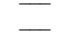 & & & & & & & & & \\
\hline romis trewavasae ephippium & MRAC 82-1 & ri face es & & Non-type & Female & & & & & & & & & & & & & & & & & 3.3 & & & & & & & & & & & & & \\
\hline
\end{tabular}




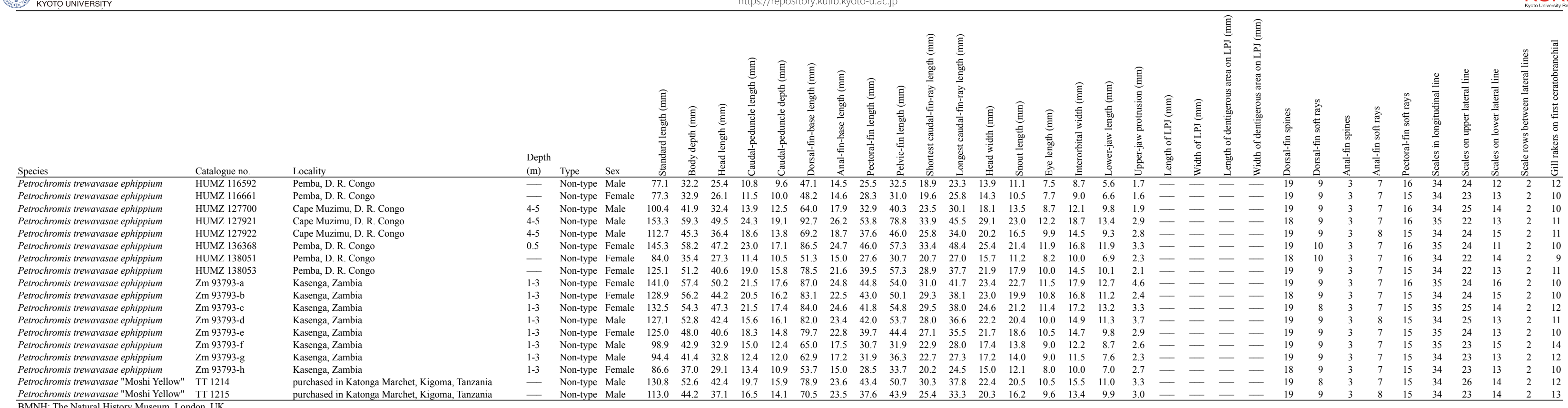

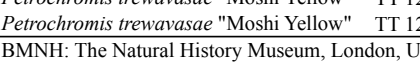

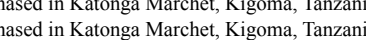
EAKU: Fish collection of Kyoto University, Kyoto and Maizuru, Japan
HUMZ: Laboratorory of Marine Biodiversity, Graduate School of Fisheries Science, Hokkaido University, Hakodate, Japan

LPJ: Lower pharyngeal jaw
MRA: Royal Museum for Central Africa, Tervuren, Belgium
NSSMTP. Depprtsent of Zology, National Science Museum,

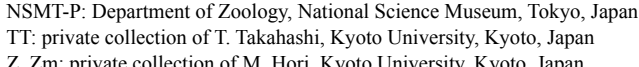

Z, Zm: private collection of M. Hori, Kyoto University, Kyoto, Japar 
Table S2 Samples used for the phylogenetic analysis

\begin{tabular}{|c|c|c|}
\hline & Names in the present study & Names in Koblmüller e \\
\hline \multirow[t]{5}{*}{ Ingroup (Tropheini) } & Chromis horei* $^{*}$ & Ctenochromis horei \\
\hline & Interochromis loocki & Interochromis loockii \\
\hline & Limnotilapia dardennii & Limnotilapia dardennii \\
\hline & Lobochilotes labiatus & Lobochilotes labiatus \\
\hline & Paratilapia pfefferi* & Gnathochromis pfeffer \\
\hline & Petrochromis famula & Petrochromis famula \\
\hline
\end{tabular}

Petrochromis fasciolatus

Petrochromis fasciolatus

Petrochromis horii n. sp.

Not used in Koblmüller et al. (2010)

Petrochromis macrognathus

Petrochromis cf. macrognathus Petrochromis orthognathus

Petrochromis polyodon

Petrochromis sp. "Katete" Pseudosimochromis curvifrons

Simochromis babault
Petrochromis sp. "Katete" Pseudosimochromis curvifrons

Not used in Koblmüller et al. (2010)

Petrochromis cf. macrognathus Petrochromis orthognathus

Petrochromis polyodon

Petrochromis cf. polyodon

Petrochromis sp. "macrognathus rainbow"

Petrochromis sp. "Texas Longola"

Petrochromis ephippium

Petrochromis trewavasae

Petrochromis sp. "Moshi yellow"

Simochromis babaulti

$\begin{array}{ll}\text { Catalogue no. } & \text { L } \\ 6621 & \text { K } \\ 6636 & \\ 6637 & \\ 6650 & \text { K } \\ 6653 & \text { W } \\ 6654 & \\ 6658 & \text { W } \\ 8037 & \text { W } \\ 8258 & \text { K } \\ 6645 & \text { K }\end{array}$

6645

7190

6619

6625

6628

6655

6614

6615

6613

6613

6620
6627

7376

8241

8252

6626

6638
6657

7058

7061

7062

8031
8032

8033

8035

MRAC B3-03-P-04

MRAC B3-03-P-05

MRAC B3-03-P-07

BMNH 2013.2.13.1

BMNH 2013.2.13.2

BMNH 2013.2.13.3

BMNH 2013.2.13.4

$\mathrm{BMNH} 20$

Zm 02170

Zm 02573

Zm 02578

Zm 02579

Zm 03532

8248

61

149
8239

8242

8242
8247

8247
6612

6622

6629

6630

6631

6632

6633

7374

7375

8236

8238

8243

8249

8261

8257
8259

8260

8234

6656

7063
$69^{* * *}$

$69^{* * *}$
$143^{* * *}$

6617

7377

8235

8245

8246

8250

6623

6624

6646
7059

7060

8240

8240
8255

8256

Locality Accession no. of DDBJ or G

ND2 $\mathrm{CR}$

Mbita Island W

GQ995716** GQ9

GQ995717** - GQ995826*

GQ995718** $\quad$ GQ995827**

GQ995742** GQ995851**

GQ995743** GQ995852**

GQ995744** GQ995853**

GQ995745** GQ995854**

GQ995746** GQ995855**

GQ995747** GQ995856**

GQ995722** GQ995831**

GQ995723** GQ995832**

GQ995724** GQ995833**

GQ995725** GQ995834**

GQ995726** GQ995835**

GQ995727** GQ995836**

GQ995728** GQ995837**

GQ995719** GQ995828**

GQ995720** GQ995829**

GQ995721** GQ995830**

GQ995729** GQ995838**

GQ995730** GQ995839**

GQ995731** GQ995840**

GQ995732** GQ995841**

GQ995733** GQ995842**

GQ995734** GQ995843**

GQ995799** GQ995908**

GQ995793** GQ995902**

GQ995800** GQ995909**

GQ995801** GQ995910**

GQ995794** GQ995903**

GQ995795** GQ995904**

GQ995796** GQ995905**

GQ995797** GQ995906**

GQ995798** GQ995907**

GQ995802** GQ995911**

AB850665 AB850680

AB850666 AB850681

AB850667 AB850682

AB850668 AB850683

AB850669 AB850684

AB850670 AB850685

AB850671 AB850686

AB850672 AB850687

AB850673 AB850688

AB850674 AB850689

AB850675 AB850690

AB850676 AB850691

AB850677 AB850692

AB850678 AB850693

AB850679 AB850694

GQ995770** GQ995879**

GQ995737** GQ995846**

GQ995738** GQ995847**

GQ995739** GQ995848**

GQ995740** GQ995849**

GQ995741** GQ995850**

GQ995749** GQ995858**

GQ995750** GQ995859**

GQ995751** GQ995860**

GQ995752** GQ995861**

GQ995753** GQ995862**

GQ995754** GQ995863**

GQ995755** GQ995864**

GQ995756** GQ995865**

GQ995757** GQ995866**

GQ995774** GQ995883**

GQ995775** GQ995884**

GQ995767** GQ995876**

GQ995768** GQ995877**

GQ995769** GQ995878**

GQ995771** GQ995880**

GQ995772** GQ995881**

GQ995773** GQ995882**

GQ995766** GQ995875**

GQ995735** GQ995844**

GQ995736** GQ995845**

GQ995759** GQ995868**

GQ995760** GQ995869**

GQ995761** GQ995870**

GQ995758** GQ995867**

GQ995764** GQ995873**

GQ995762** GQ995871**

GQ995763** GQ995872**

GQ995765** GQ995874**

GQ995748** GQ995857**

GQ995776** GQ995885**

GQ995777** GQ995886**

GQ995778** GQ995887**

GQ995779** GQ995888**

GQ995784** GQ995893**

GQ995786** GQ995895** 
A Self-archived copy in

\begin{tabular}{|c|c|c|c|c|c|c|}
\hline & & & & & Accession no. & r GenBank \\
\hline & Names in the present study & Names in Koblmüller et al. (2010) & Catalogue no. & Locality & ND2 & $\mathrm{CR}$ \\
\hline & Simochromis diagramma & Simochromis diagramma & 6649 & Kalambo Lodge & GQ995790** & GQ995899** \\
\hline & & & 8038 & Wonzye & GQ995791** & GQ995900** \\
\hline & & & 8244 & $\mathrm{~S}$ of Isonga & GQ995792** & GQ995901** \\
\hline & Simochromis marginatus & Simochromis marginatus & 64 & Ubwari & GQ995789** & GQ995898** \\
\hline & & & 8253 & Mahale N & GQ995787** & GQ995896** \\
\hline & & & 8254 & Mahale N & GQ995788** & GQ995897** \\
\hline & Simochromis pleurospilus & Simochromis pleurospilus & 6611 & Kalambo Lodge & GQ995780** & GQ995889** \\
\hline & & & 6616 & Kalambo Lodge & GQ995781** & GQ995890** \\
\hline & & & 6639 & Mbita Island $\mathrm{W}$ & GQ995782** & GQ995891** \\
\hline & & & 8039 & Mbita Island W & GQ995783** & GQ995892** \\
\hline & Tropheus duboisi & Tropheus duboisi & 76 & Bemba & GQ995804** & GQ995913** \\
\hline & & & $85^{* * * *}$ & Maswa & GQ995806** & GQ995915** \\
\hline & & & $91 * * *$ & Maswa & GQ995807** & GQ995916** \\
\hline & & & 101 & Bemba & GQ995805** & GQ995914** \\
\hline & & & 3441 & Location unknown & GQ995803** & GQ995912** \\
\hline & & & 4518 & Halembe & GQ995808** & GQ995917** \\
\hline & & & 4519 & Halembe & GQ995809** & GQ995918** \\
\hline & Tropheus species complex & Tropheus brichardi & $\operatorname{Tr} 10$ & Bulombora & GQ995817** & GQ995926** \\
\hline & & Tropheus moorii & 4300 & Mbita Island W & GQ995810** & GQ995919** \\
\hline & & Tropheus polli & 5447 & Kekese & GQ995818** & GQ995927** \\
\hline & & & 5448 & Kekese & GQ995819** & GQ995928** \\
\hline & & Tropheus sp. & $\operatorname{Tr} 8$ & Kapampa & GQ995816** & GQ995925** \\
\hline & & & $4370 * * *$ & Kachese & GQ995811** & GQ995920** \\
\hline & & & $4374 * * *$ & Mpimbwe & GQ995812** & GQ995921** \\
\hline & & & $4376^{* * *}$ & Bemba & GQ995813** & GQ995922** \\
\hline & & & 4385 & Nakaku & GQ995814** & GQ995923** \\
\hline & & Tropheus sp. "Kirschfleck" & $4520^{* * *}$ & Mabilibili & GQ995815** & GQ995924** \\
\hline Outgroup & Astatotilapia burtoni & Astatotilapia burtoni & 7054 & & GQ995713** & GQ995822** \\
\hline & & & 7055 & & GQ995714** & GQ995823** \\
\hline & & & 7056 & & GQ995715** & GQ995824** \\
\hline & Aulonocara sp. & Aulonocara sp. & $6662 * * *$ & & GQ995712** & GQ995821** \\
\hline & Copadichromis borleyi & Copadichromis borleyi & $6661 * * *$ & & GQ995711** & GQ995820** \\
\hline
\end{tabular}

* Generic allocation has not been resolved, so the combination shown in the original description of the species is tentatively used.

** Koblmüller et al. (2010)

*** Samples obtained through ornamental fish trade. 